\title{
Landslide Hazards in Vermont
}

\section{U.S. GEOLOGICAL SURVEY BULLETIN 2043}

Prepared in cooperation with the

Vermont Geological Survey

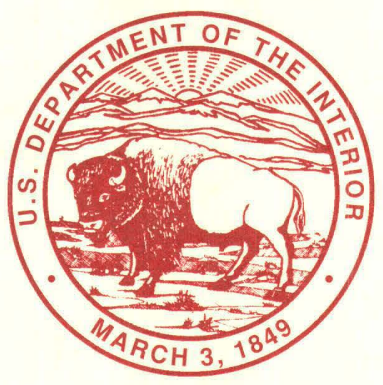




\section{AVAILABILITY OF BOOKS AND MAPS OF THE U.S. GEOLOGICAL SURVEY}

Instructions on ordering publications of the U.S. Geological Survey, along with prices of the last offerings, are given in the current-year issues of the monthly catalog "New Publications of the U.S. Geological Survey." Prices of available U.S. Geological Survey publications released prior to the current year are listed in the most recent annual "Price and Availability List." Publications that may be listed in various U.S. Geological Survey catalogs (see back inside cover) but not listed in the most recent annual "Price and Availability List" may be no longer available.

Prices of reports released to the open files are given in the listing "U.S. Geological Survey Open-File Reports," updated monthly, which is for sale in microfiche from U.S. Geological Survey ESIC-Open-File Report Sales, Box 25286, Denver, CO 80225. Reports released through the NTIS may be obtained by writing to the National Technical Information Service, U.S. Department of Commerce, Springfield, VA 22161; please include NTIS report number with inquiry.

Order U.S. Geological Survey publications by mail or over the counter from the offices given below.

\section{BY MAIL}

\section{Books}

Professional Papers, Bulletins, Water-Supply Papers, Techniques of Water-Resources Investigations, Circulars, publications of general interest (such as leaflets, pamphlets, booklets), single copies of Earthquakes \& Volcanoes, Preliminary Determination of Epicenters, and some miscellaneous reports, including some of the foregoing series that have gone out of print at the Superintendent of Documents, are obtainable by mail from

\section{U.S. Geological Survey, Map Distribution Box 25286, Bldg. 810, Federal Center Denver, CO 80225}

Subscriptions to periodicals (Earthquakes \& Volcanoes and Preliminary Determination of Epicenters) can be obtained ONLY from the

\section{Superintendent of Documents \\ Government Printing Office \\ Washington, D.C. 20402} Documents.)

(Check or money order must be payable to Superintendent of Maps

For maps, address mail orders to

\section{U.S. Geological Survey, Map Distribution Box 25286, Bldg. 810, Federal Center Denver, CO 80225}

Residents of Alaska may order maps from

\author{
U.S. Geological Survey, Earth Science Information Center \\ 101 Twelfth Ave. - Box 12 \\ Fairbanks, AK 99701
}

\section{OVER THE COUNTER}

\section{Books and Maps}

Books and maps of the U.S. Geological Survey are available over the counter at the following U.S. Geological Survey offices, all of which are authorized agents of the Superintendent of Documents:

- ANCHORAGE, Alaska-Rm. 101, 4230 University Dr.

- LAKEWOOD, Colorado-Federal Center, Bldg. 810

- MENLO PARK, California-Bldg. 3, Rm. 3128, 345 Middlefield $\mathrm{Rd}$.

- RESTON, Virginia-USGS National Center, Rm. 1C402, 12201 Sunrise Valley Dr.

- SALT LAKE CITY, Utah-Federal Bldg., Rm. 8105, 125 South State St.

- SPOKANE, Washington-U.S. Post Office Bldg., Rm. 135, West 904 Riverside Ave.

- WASHINGTON, D.C.-Main Interior Bldg., Rm. 2650, 18th and C Sts., NW.

\section{Maps Only}

Maps may be purchased over the counter at the following U.S. Geological Survey offices:

- FAIRBANKS, Alaska-New Federal Bldg., 101 Twelfth Ave.

- ROLLA, Missouri-1400 Independence Rd.

- STENNIS SPACE CENTER, Mississippi-Bldg. 3101 


\section{Landslide Hazards in Vermont}

By CHARLES A. BASKERVILLE, FITZHUGH T. LEE, and CHARLES A. RATTÉ

Prepared in cooperation with the

Vermont Geological Survey

A discussion of recent and historic landslides in Vermont, detailing hazards, processes, and slope movement in numerous soil and rock types 


\title{
U.S. DEPARTMENT OF THE INTERIOR BRUCE BABBITT, Secretary
}

\author{
U.S. GEOLOGICAL SURVEY \\ Dallas L. Peck, Director
}

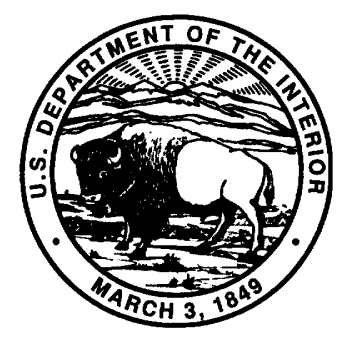

Any use of trade, product, or firm names

in this publication is for descriptive purposes only

and does not imply endorsement by the U.S. Government.

For sale by

U.S. Geological Survey, Map Distribution

Box 25286, Bldg. 810, Federal Center

Denver, CO 80225

Library of Congress Cataloging in Publication Data

Baskerville, Charles A.

Landslide hazards in Vermont / Charles A. Baskerville, Fitzhugh T. Lee, Charles

A. Ratté

p. cm.-(U.S. Geological Survey bulletin ; 2043)

Includes bibliographical references.

Supt. of Docs. no.: I 19.3:2043

1. Landslides-Vermont. I. Lee, Fitzhugh T. II. Ratté, Charles A. III. Title. IV. Series.

QE75.B9 no. 2043

[QE599.U5]

$557.3 \mathrm{~s}-\mathrm{dc} 20$

[551.3'07]

92-23611 


\title{
CONTENTS
}

\author{
Abstract 1 \\ Introduction 1 \\ Natural Slope Processes in Soil and Bedrock 1 \\ Mass Movement of Soils and Debris 1 \\ Mass Movement of Bedrock 1 \\ Human-Induced Slope Instability $\mathbf{2}$ \\ Active Geomorphic Processes Contributing to Instability 3 \\ Acknowledgments $\mathbf{3}$ \\ Historical Record of Slope Movement in Vermont 3 \\ Research Investigations $\mathbf{5}$ \\ Movements of Soil Materials on Slopes 6 \\ Soil Types in Vermont $\mathbf{6}$ \\ Types of Soils in which Slope Movements Occur in Vermont 6 \\ Natural and Human-Induced Slope Movements in Vermont Soils 8 \\ Differing Rates of Movement in Soils in Vermont 9 \\ Debris Avalanches $\mathbf{1 0}$ \\ Slope Remediation $\mathbf{1 1}$ \\ Slope Movements in Bedrock $\mathbf{1 2}$ \\ Conditions that Promote Rock-Slope Movement 12 \\ Types of Structural Discontinuities in Rock 13 \\ Rock-Slope Movement Types 13 \\ Rockfall 13 \\ Block Slides 14 \\ Topples 14 \\ Slope Movements on Vermont's Interstate Highways 16 \\ History and Construction of the System 16 \\ General Geology 18 \\ Design, Design Changes, and Construction of Rockcuts 18 \\ Analysis of Rockcuts $\mathbf{2 0}$ \\ Rockcut Slope Failures 20 \\ Results of the Phase I Project $\mathbf{2 2}$ \\ Conclusions $\mathbf{2 2}$ \\ References Cited 22
}

\section{FIGURES}

1, 2. Photographs showing:

1. The intensity of jointing in the Cheshire Quartzite 2

2. An example of a vertical joint set with a second set intersecting at a large angle 2

3. Map showing locations of soil landslide sites described in the text 4

4, 5. Photographs showing:

4. A, The 1984 debris flow on East Mountain at Mendon, looking downslope;

$B$, The same slide area, looking upslope, from U.S. Route 4 a year later 6

5. A rhythmite sequence at North Springfield flood-control reservoir 7 
6. Diagram illustrating a typical rhythmite sequence 7

7-12. Photographs showing:

7. Shoreline slope failure on Lake Champlain near Vergennes $\mathbf{8}$

8. A slide being repaired on East Mountain, Mendon 9

9. A debris avalanche scar from failure on August 10, 1976, on Dorset Mountain $\mathbf{1 0}$

10. The riprap berm used to add weight to the toe of a slope on a road shoulder after a slide west of Bridgewater Corners on U.S. Route $4 \mathbf{1 2}$

11. The Andover Brook where it has undercut its bank in front of this house 12

12. The corrugated vertical drain used at Killington Mountain $\mathbf{1 2}$

13. Map showing locations of some rock-slope movements in western Vermont 14

14. Generalized section through Smugglers Notch showing rockfalls and debris accumulation at the base of the slope

14

15-17. Photographs showing:

15. The 6,000-ton King Rock on Vermont Route 108 in Smugglers Notch 15

16. Block slide at White Rocks, near Wallingford, south of Rutland $\mathbf{1 5}$

17. Damage to trees caused by blocks of Cheshire Quartzite tumbling down the dip slope 15

18. Diagram showing slope deformation in Cheshire Quartzite at Mad Tom Brook, looking west 16

19. Map showing the location of Interstates 89 and 91 and the periods of their incremental construction and locations of rockslides and rockfalls 17

20. Generalized geologic map of Vermont 19

21-25. Photographs showing:

21. The rockslide of May 4, 1985, along the southbound roadway of Interstate 89 at South Barre 20

22. The Palisades rockcut at Fairlee 21

23. A vehicle damaged by the March 9,1987 , rockfall at location 5 shown in figure $19 \mathbf{2 1}$

24. The scar of the October 10,1968 , rockslide near Interchange 6 (Rockingham) on Interstate 9121

25. The scar and resulting debris of the April 30, 1977, rockslide along the southbound cut face of Interstate 91 at Fairlee

\section{TABLES}

1. Types of discontinuities in rock causing failure of slopes $\mathbf{1 3}$

2. Criteria used in the 1977-78 analysis of rockslide-rockfall potential along

Vermont's Interstate Highway System

20 


\title{
Landslide Hazards in Vermont
}

\author{
By Charles A. Baskerville, ${ }^{1}$ Fitzhugh T. Lee, ${ }^{2}$ and Charles A. Ratté ${ }^{3}$
}

\section{Abstract}

Landslides are one of the major geologic processes that cause change on the Earth's surface. Many landslides in Vermont involve unconsolidated materials such as colluvium, various glacial materials, and glacial lakebed deposits. Naturally occurring slides are common along riverbanks as part of the process of stream erosion. Landslides, including debris slides, debris flows and avalanches, earth slumps, and a variety of wet soil flows, develop in many areas because of the presence of unconsolidated materials. Slides can also result from human activity. For example, improper design of cut slopes for highways can give rise to slope failures. Two hundred years ago (1783), Vermont landslides were made famous in newspaper accounts of devastating spring flood events. Such slope movement can cause economic losses as well as loss of life.

The mountainous areas of Vermont are underlain by fractured bedrock that typically has a very thin soil cover. The nature and orientation of joints, faults, foliation, and bedding, which are called geologic discontinuities, are the main factors in rock-slope stability. In addition, several natural factors such as precipitation and freeze-thaw action play an important part in rock-slope stability, as well as does topography. The predominant types of rockslope failures in Vermont are rockfalls, block slides, and topples. Although the majority of falls involve a small quantity of rock, they typically occur without warning. Debris avalanches triggered by rockfalls have occurred in western and central Vermont, where they typically take place on south-facing slopes in foliated metamorphic rocks.

Design and construction considerations for rockcuts in Vermont's Interstate Highway System (I-89 and I-91) were constrained by economics. Construction began in 1956 and was completed in 1982. Consideration of rock structure was not taken into account in the design of slopes that had cut rocks.

Manuscript approved for publication, July 16, 1992.

${ }^{1}$ U.S. Geological Survey. Present address: Department of Physics and Earth Sciences, Central Connecticut State University, 1615 Stanley St., New Britain, CT 06050-4010.

${ }^{2}$ U.S. Geological Survey. Present address: 211-2 Bluffs Dr., Kala Point, Port Townsend, WA 98368.

${ }^{3}$ State Geologist, State of Vermont, Agency of Natural Resources, 103 South Main St., Center Building, Waterbury, VT 05676. Present address: Department of Geological Sciences, Bowman Hall, University of Kentucky, Lexington, KY 40506-0059.

\section{INTRODUCTION}

The primary agents required to trigger slope movement processes are gravity and precipitation (Hamblin, 1989). In Vermont's climate and with its glaciated mountainous terrain, these ingredients are frequently present. Steep slopes promote gravitational acceleration. Heavy winter snows are accompanied by spring melting; heavy rains occur in the spring and fall.

As the pressure for development of potentially unstable areas increases, it becomes critical that slope movements and their causes are analyzed and explored. When slope stability problems in Vermont are being addressed, determination of the engineering characteristics of the various soil and rock types present in the differing geomorphic settings is paramount.

\section{Natural Slope Processes in Soil and Bedrock}

Soils. - The use of the term "soil" in this report is in the engineering sense; that is, soil consists of unconsolidated material such as clastic sediment, weathered bedrock, rock fragments, and organic matter (Varnes, 1978). This term is synonymous with earth.

Debris. - This term refers to material containing a relatively high percentage of coarse fragments (Varnes, 1978).

\section{Mass Movement of Soils and Debris}

Many types of mass movement on slopes involve soil and debris, including debris slides, debris flows, earth flows, and debris avalanches. Debris avalanches at times may be carried on a cushion of air and (or) water. Except for dry flows, the rapidity of flow depends on water content and slope angle (Varnes, 1958).

\section{Mass Movement of Bedrock}

Bedrock.-Discontinuities control the stability and the failure mode of bedrock slopes. "Discontinuity" in this report refers to bedding in sedimentary rocks, foliation in metamorphic rocks, and simple to complex joint sets in various rock masses. 


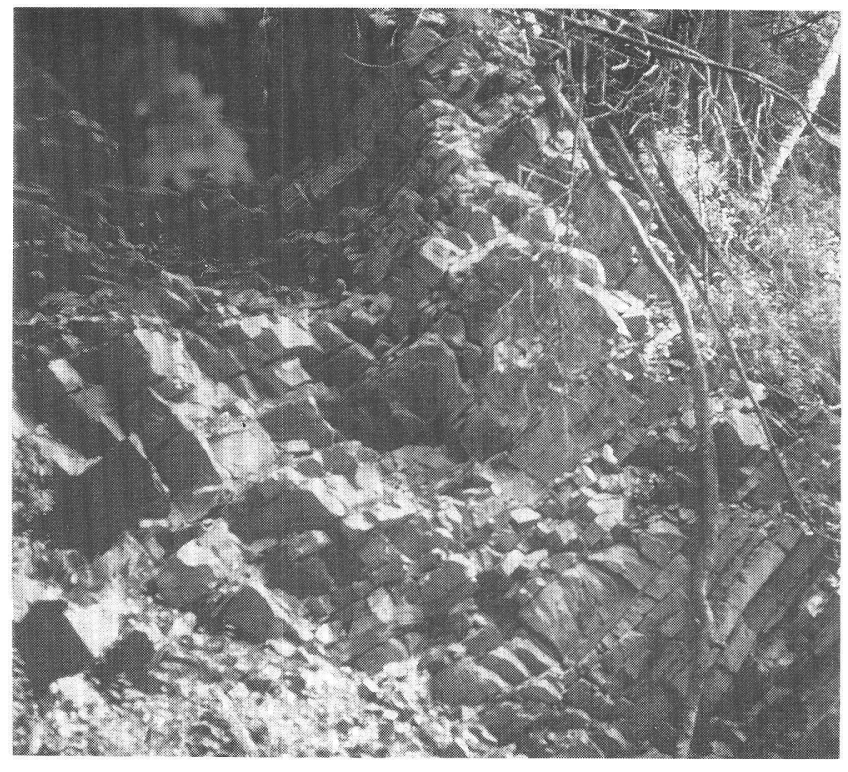

Figure 1. The intensity of jointing in the Cheshire Quartzite facilitates failure by allowing gravity as well as normal freeze-thaw action to open the joints more rapidly.

Mass movements in bedrock include (1) rock topples, which occur when tall, slender blocks of rock fall forward because their center of gravity is high - a block of this type will rotate about its lowest contact edge (forward edge) (Hoek and Bray, 1977); (2) rotational rock slumps, which occur when forces cause a backward rotation about a point above the center of gravity; this movement is extremely slow to moderate; (3) block slides, which occur when there is translational movement of a coherent mass of rock along a relatively planar surface; (4) lateral spreads, which are movements in a fractured mass distributed as a lateral extension; and (5) rockfalls and rockslides, which may be moderate to rapid in movement (Varnes, 1978). A rockfall is a fall of a newly detached mass from an area of bedrock, and a rockslide is movement consisting of shear strain and displacement along a surface or surfaces that may be visible or inferred (Varnes, 1978). Rockfalls can trigger debris avalanches (Baskerville and others, 1988; Jibson, 1989).

Failure of a jointed bedrock slope commonly occurs where two intersecting joint surfaces emerge on a slope face to form a V-shaped notch (fig. 1). Hydrostatic pressure along joint surfaces can reduce the effective stress and cause sliding in the rock mass bordered by these joints.

Toppling failures develop when planar discontinuities are about vertical and subparallel. The rock column thus created is prone to fail, especially where another set of planar surfaces intersects the vertical surfaces at some large angle (fig. 2). Hydrostatic pressure and frost wedging will help push away the failing column or block from the main rock mass.

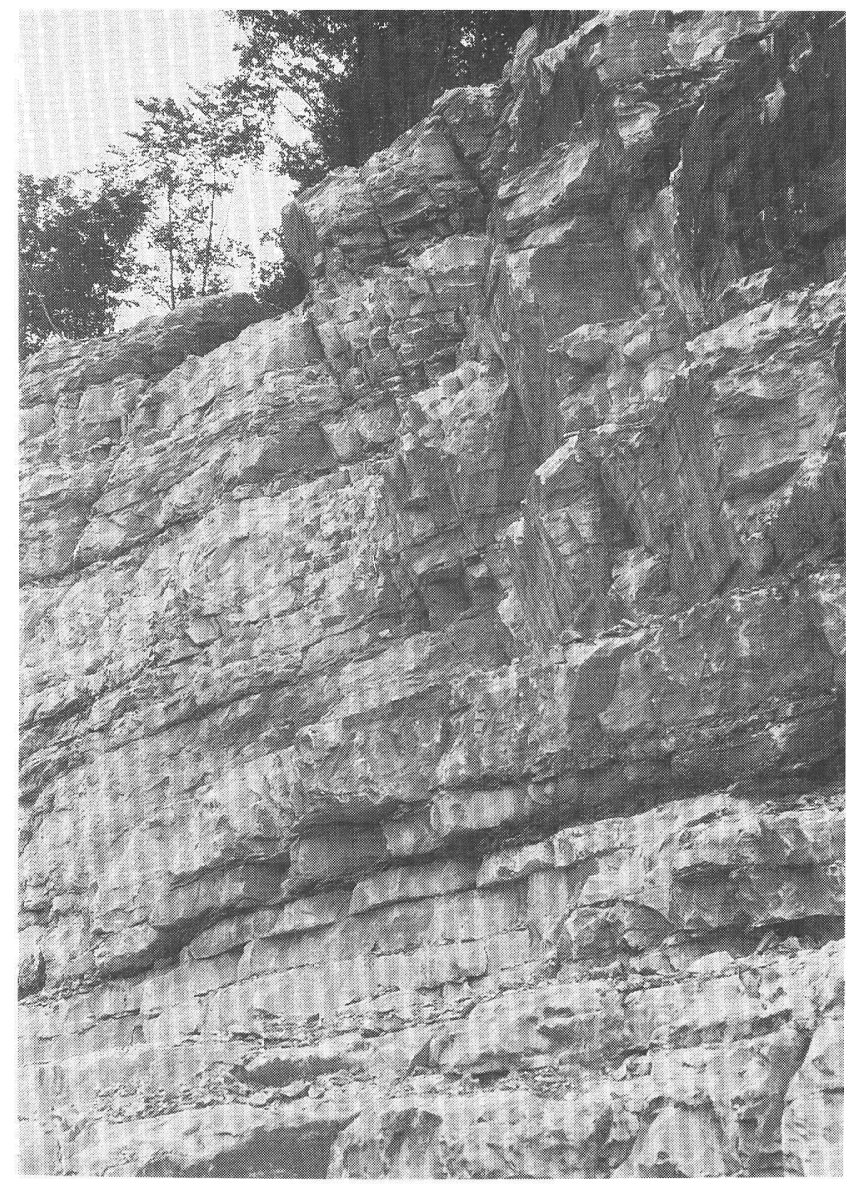

Figure 2. An example of a vertical joint set (upper right) with a second set intersecting at a large angle (subhorizontal). Toppling failure would occur in the direction of dip of the subhorizontal joint set. This site is on U.S. Route 7 near East Dorset.

\section{Human-Induced Slope Instability}

Although many landslides are due to natural geomorphic processes, slope instability can also be aided by the actions of humans. Causes of human-induced failures recognized in Vermont include insufficient design of stormwater drainage systems, improper construction and maintenance of logging roads, and inadequate design of slope cuts made for highways.

About $520 \mathrm{~km}$ of four-lane Interstate Highways (I-91 and I-89 plus short links) were built in Vermont between 1956 and 1982. During the early years of Interstate Highway construction, the general emphasis was on keeping excavation and right-of-way costs at a minimum (El Ashmawi and Greenfield, 1972). There was little experience in slope-cut design for highways, particularly in strongly foliated, heavily fractured, steeply dipping metamorphic rocks. Slope stability considerations in Vermont during the 1950's were in their infancy (Sharpe, 1989). By the early 1970 's, Federal highway safety specifications were enforced 
in Vermont when the government required widening of all pre-1971 rockcuts to a 9-m clear zone from the edge of the pavement (Vermont Department of Highways, 1971).

\section{Active Geomorphic Processes Contributing to Instability}

Whether the failing slopes are rock or soil, the active processes include factors that generate high shear stresses and low shear strength (Varnes, 1958). One factor generating high shear stress is removal of lateral support. This loss of support can come about by stream erosion or, as along the shores of Lake Champlain, erosion by waves and associated longshore currents. High shear stresses can also come about by construction of highway rockcuts, by adding unevenly distributed weight to subsoil as a result of building highway embankment fills, and by earthquakes. In contrast, low shear strength in soil results from such factors as increased moisture content. In rock, low shear strength is attributed to weathering and discontinuities. Along discontinuities such as joints, faults, and cleavage, high porewater pressure due to rainfall or snowmelt can also develop, and this pressure decreases strength of rocks.

\section{Acknowledgments}

We thank the Vermont Agency of Transportation for their cooperation in supplying data on slides affecting various highways. Special appreciation is extended to Roy Nickelson, former Director of the Materials Division, and Frank Lanza, former Chief Geologist of the Vermont Agency of Transportation, for their suggestions. We are also grateful for the constructive peer reviews given this manuscript by Gerald Wieczorek and Eleanora Robbins of the U.S. Geological Survey.

\section{HISTORICAL RECORD OF SLOPE MOVEMENT IN VERMONT}

While researching historical data as far back as 1783 to learn about slope failures in Vermont, we discovered that the term "landslide" or any related terms were not used in accounts earlier than 1796, although widespread damage from floods is mentioned. For example, in Spooner's Vermont Journal, May 27, 1796, the following account appeared: "In the afternoon of Sunday, the 15th inst. [sic] was experienced at the upper part of this state, the most uncommon shower of rain ever known in this country . . . many mill dams and bridges were carried away, and roads injured materially."

Additional historical examples describe a significant amount of damage due to storms. (See fig. 3 for site locations.) It was noted that the words "landslide" and "slide" began to appear after the first quarter of the 19th century:

July 22, 1811 (Spooner's Vermont Journal, August 12, 1811):

In Ira [site 1, fig. 3], the inhabitants were not exempt from the general calamity. The waters in the east part of the town carried the most awful destruction over a beautiful tract of land of many hundred acres, and in many instances totally destroyed the soill.... A number of once beautiful farms now exhibit a dreary waste of rocks and flood wood.... Where once were meadows and fields of grain, nothing but huge rocks and trees, torn from hills and mountains, are now to be seen .... The mass of rocks and trees which were brought from the mountains, is wonderful to behold. Trees which measured one, two and three feet through, are strewed over hundreds and hundreds of acres of the once fertile plains ... and in some instances piled up 20 and 30 feet high. Also, rocks which probably weighed several tons, covered the rich and fertile vale of several hundred acres.

June 3, 1827 (Monthly Weather Review, July 1897, U.S. Department of Agriculture, Weather Bureau):

Warren, Vt. [site 2, fig. 3] . . a about 100 acres slid from Fayston Mountain down to the valley beneath.

Circa 1870 (no day or month given) (Rutland Herald, March 24, 1920):

Near the northern opening of the [Smugglers] Notch, and about four miles from Carlton's hotel in Cambridge [site 3, fig. 3] . . . is a large rock about 60 feet in circuit, which became detached from its parent bed far up the mountain side about 50 years ago, and came thundering down the valley, laying waste the giant trees and whatever chanced to be in its downward course, producing a rumbling not unlike an earthquake, which heard far off, and shook the hills for miles around.

July 1897 (Monthly Weather Review, July 1897, U.S. Department of Agriculture, Weather Bureau):

The landslide of the present month [Wednesday, July 14, 1897] had been preceded by heavy rains, but it seems to have been started by the fall of an immense boulder near the top of the mountain [Mt. Ellen] in the northwest of Warren township at an altitude of about 3890 feet [site 8, fig. 3]. Simultaneously, another slide began at a point a little south of this boulder; the two slides joined together after a path of about 100 rods, and the combined avalanche continued not only 


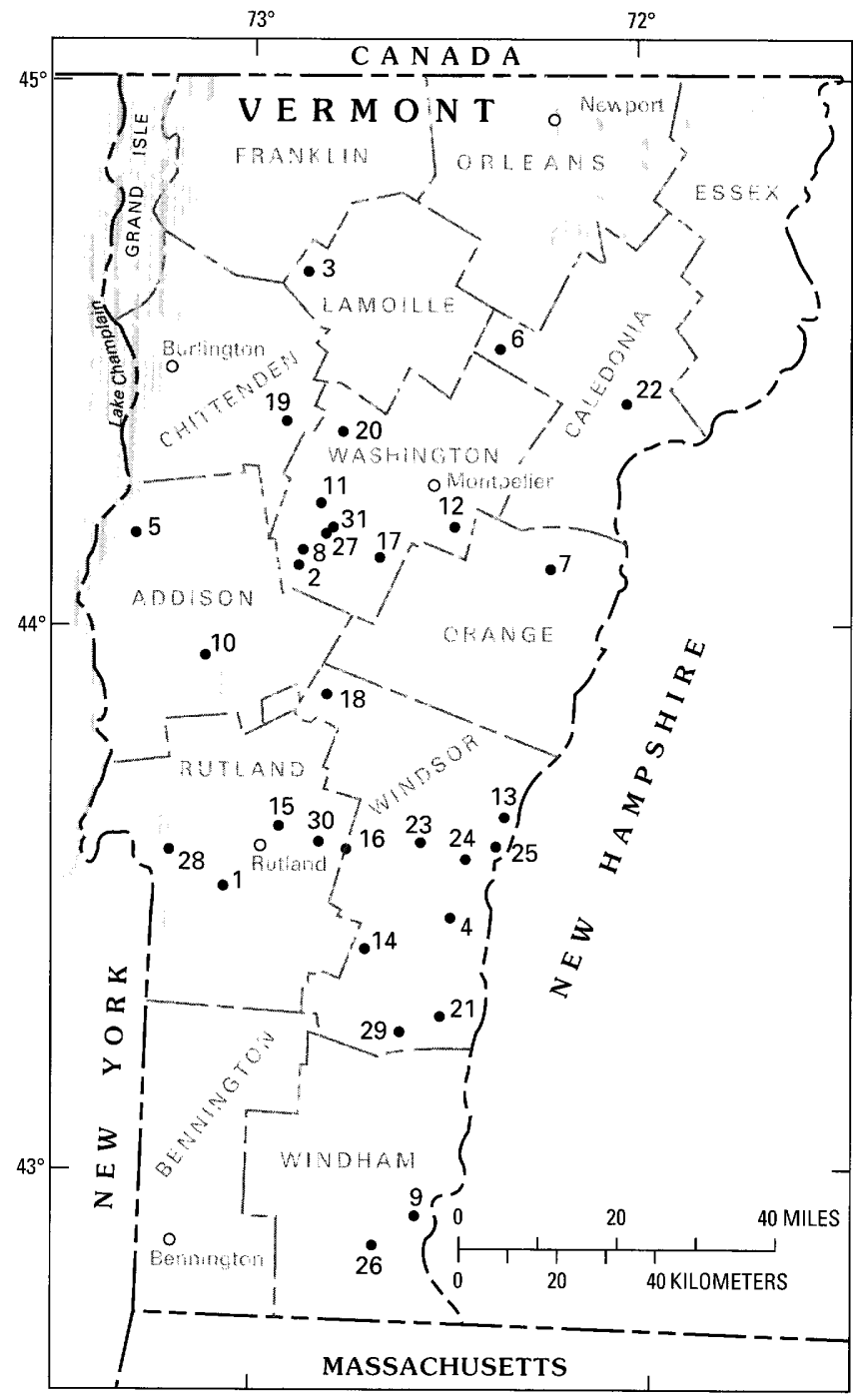

Figure 3. The locations of soil landslide sites described in the text. A few cities are shown directly on the map; other locations are shown by number and listed below.

$\begin{array}{ll}1 \text { Ira } & 16 \text { West Bridgewater } \\ 2 \text { Warren } & 17 \text { Northfield } \\ 3 \text { Cambridge } & 18 \text { Rochester } \\ 4 \text { Brownsville } & 19 \text { Bolton } \\ 5 \text { Vergennes } & 20 \text { Waterbury } \\ 6 \text { Hardwick } & 21 \text { Springfield } \\ 7 \text { Topsham } & 22 \text { St. Johnsbury } \\ 8 \text { Clay Brook } & 23 \text { Woodstock } \\ 9 \text { East Dummerston } & 24 \text { Hartland Four Corners } \\ 10 \text { East Middlebury } & 25 \text { North Hartland } \\ 11 \text { Fayston } & 26 \text { Marlboro } \\ 12 \text { Barre } & 27 \text { Irasville } \\ 13 \text { White River Junction } & 28 \text { Castleton } \\ 14 \text { Ludlow } & 29 \text { Chester } \\ 15 \text { Mendon } & 30 \text { Killington Mountain } \\ & 31 \text { Waitsfield }\end{array}$

three miles eastward to the foot of the mountain, but a mile farther over comparatively level ground .... The foot of the slide now covers an area of nearly a quarter of a mile square . . . about 1300 to 1478 feet above sea level, making an actual fall for the whole mass of about 2400 feet. The slide apparently ran down the ravine occupied by Clay Brook and landed at its mouth in the valley of the Mad River.

April 1, 1920 (Rutland Herald, April 1, 1920):

... moving out of the ice jam opposite this village, which caused two slides on the Boston and Maine railroad ... the roadbed north of the junction of the Connecticut and West Rivers slid out for a distance of 150 feet making a gulch 30 feet deep and leaving the track suspended in mid-air. A similar slide occurred north of the Dummerston station [site 9, fig. 3], being 100 feet long and 20 feet deep.

March 8, 1922 (Rutland Herald, March 8, 1922):

Heavy flooding as temperatures go to 20 degrees above freezing for two days ... rain and melting snow send all streams over their banks in torrents . . . railroads and trolley tracks were inundated along with roads and low lying fields in East Middlebury [site 10, fig. 3] and Rutland and Fayston [site 11, fig. 3]. A landslide from a bank near Fort Ethan Allen covered the tracks of the Central Vermont railroad on March 7 (at night).

April 13, 1922 (Rutland Herald, April 13, 1922):

. . . after two days of rain over all of Vermont ... landslides hinder railroad traffic... bridges out, trains derailed... mountain streams overflowing their banks... many miles of highways damaged ... damage in hundreds of thousands of dollars.

November 3-7, 1927 (Rutland Herald, excerpts cover November 3-7, 1927):

... seven inches of rain in less than 18 hours .... Property damage in Rutland was estimated at $\$ 500,000 \ldots$. . In Bennington [fig. 3] water reached the second floor of some homes . . . Nine lost their lives in Barre [site 12, fig. 3]. At least 8 fatalities were reported by November $5 \ldots$. The Lt. Governor perished in flood in Montpelier [fig. 3] where waters were 20 feet deep . . . . Damage in the Connecticut River Valley between St. Johnsbury [site 22, fig. 3] and Bellows Falls was estimated at $\$ 1,000,000 \ldots$. A reservoir collapse in Montpelier was said to have killed 137 to 212 people . . . . Damage at White River Junction [site 13, fig. 3] estimated at $\$ 1,500,000$. Water rose 30 feet in the river in 12 hours killing $3 \ldots$. . A landslide on Mt. Tabor [site 5, fig. 13] carried rocks and timber down slope.... Montpelier and Barre 
flood losses $\$ 4,000,000 \ldots$... Many landslides occurred near Ludlow [site 14, fig. 3] and in the Connecticut River Valley . . . . Landslides occurred in Mendon Woods between West Bridgewater [site 16, fig. 3] and Rutland. From Cary's Mills down Rochester Mountain to Rochester [site 18, fig. 3], landslides covered the roads.... Northfield [site 17, fig. 3] on the Dog River, Moretown and other towns in the Mad River Valley along with Bolton and Waterbury in the Winooski Valley suffered heavily from the disastrous flood . . . 3000 cattle drown in Winooski Valley ... over 50 persons killed... Entire hills from Bolton [site 19, fig. 3] to Waterbury slid into the river . . . . A landslide occurred on Lincoln Mountain about two miles from Warren [site 2, fig. 3]. Landslides also occurred between Northfield and Roxbury along with washouts.

April 11, 1934 (Rutland Daily Herald, April 11, 1934): Montpelier-Winooski River rose to the high water mark by 10 P.M. . . . Gale driven rainstorms caused thousands of dollars worth of damage throughout Vermont.... Landslides and washouts blocked main highways.... Ground was still frozen and unable to absorb the water. Heavy snow fell in the mountains.... A landslide cut off the highway between Springfield [site 21, fig. 3], Vermont and Charlestown, New Hampshire . . . .

In 1934, construction began on the Winooski Valley flood control project by the Civilian Conservation Corps (CCC) and the Army Corps of Engineers to ease damage from floods of the 1927 proportions (Rutland Daily Herald, October 18, 1934). The 1927 floods and slides took numerous lives and did $\$ 13,500,000$ in property damage. This project included the Wrightsville Dam (completed in 1935) on the North Branch, a tributary to the Winooski River, at the northern outskirts of Montpelier (fig. 3). The North Branch flows through the heart of Montpelier joining the Winooski within a few blocks of the State Capitol. The flood control dams in the Winooski basin "tamed the roaring waters" (Rutland Daily Herald, March 13, 1936).

But on March 13, 1936, torrential rains, landslides, and avalanches killed three people, and two others drowned in other wild streams. In the same month, a large snowslide blocked the road between St. Johnsbury and Newport (fig. 3). By March 19, flood deaths in Vermont had increased by another five. There were washouts and frequent landslides between Bridgewater and Woodstock (site 23, fig. 3 ) in the Ottauquechee Valley. The flood waters were higher during these 1936 events than in 1927. Food shortages and spoilage were big factors in 1936 due to electric power failure that shut down the use of refrigerators. Spoilage of food in 1927 was not a factor because refrigeration was with ice (Rutland Daily Herald, March 19, 1936). According to then State Works Progress Administration (WPA) administrator, Harry W. Witters, overall damage was less in 1936 than 1927 because of construction of hard surface roads and new bridges since 1927 (Rutland Daily Herald, March 19, 1936). In the spring of 1936, Congress appropriated $\$ 13,373,000$ to construct a system of 10 reservoirs on the Upper Connecticut River in New England. These funds came out of a Senate Commerce Committee bill for $\$ 305,000,000$ for flood control projects in the recently flooded Eastern States.

This short digest of landslides and floods in Vermont covers 150 years from the late 18 th into the early 20 th century. With the amounts of precipitation and flooding described, some slope failures also undoubtedly occurred. The slope movements probably did not affect the valley dwellers to the same extent as did the floods. The floods that devastated Connecticut Valley communities during the 1920 's and 1930's led to construction of numerous flood control projects by the Army Corps of Engineers on many Connecticut River tributaries. While these structures have solved the major flooding conditions, potential for landsliding remains. For example, in 1976, and again in 1984, slides occurred on East Mountain in Mendon, (site 15, fig. 3) and blocked U.S. Route 4 (fig. 4).

\section{Research Investigations}

We conducted research on slope-movement problems in the State of Vermont from 1983 through 1989. One of the goals of this work has been to determine the dominant processes that activate these slope failures. We took measurements of some of the slope failures so we could begin to understand the magnitude of these processes. These measurements included length and width of various categories of landslides that included soil. Auger holes were also drilled in landslides and logged. These data were used to determine the volume of material in each slide. Additionally, we performed field tests, such as the vane shear and penetrometer, to determine engineering characteristics of the materials. Both disturbed (shovel) samples and undisturbed (pressed in Shelby tubes) samples of landslide materials were taken. These samples were used for such tests as grain-size distribution and unconfined compressive strength. X-ray analyses were performed on many of these samples to determine the amount and types of clay and other minerals in the slide masses. This information assisted in the determination of whether certain clays may have contributed to slide movement and whether the clay minerals are prone to absorbing large volumes of water (Baskerville and Ohlmacher, 1988; Ohlmacher and Baskerville, 1991). In the study of bedrock failures, we applied dial-gage and tape extensometer instrumentation to some of the rock slopes in areas where potential for failures was suspected, including Smugglers Notch, White Rocks Recreation Area, and Mad Tom Brook (Lee, 1989). 


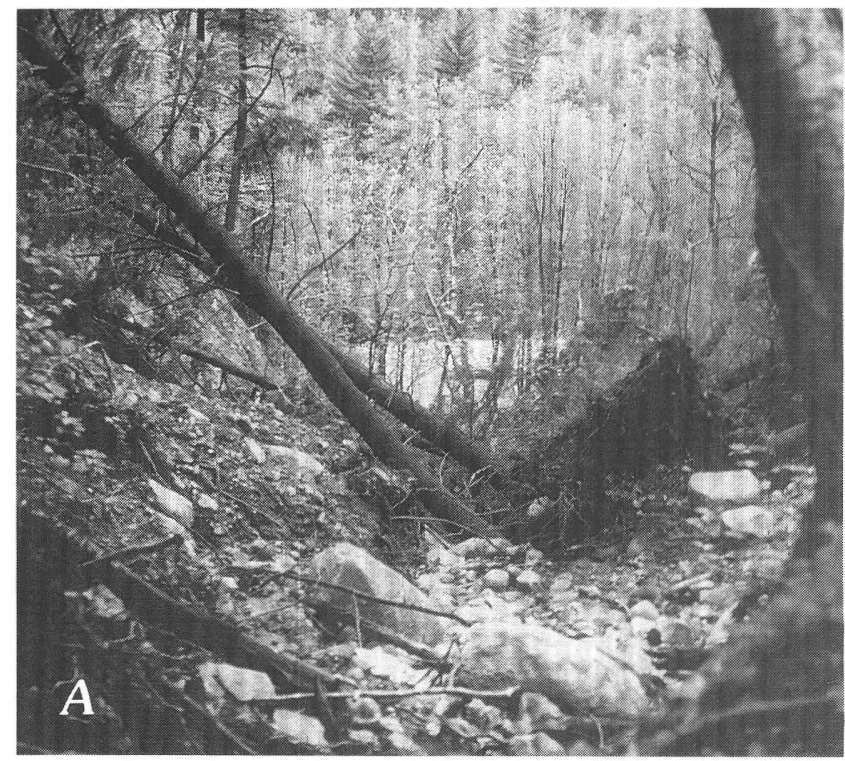

Figure 4. $A$, The 1984 debris flow on East Mountain at Mendon, looking downslope; clear area in background is pavement of U.S. Route 4. This slide developed when a breach occurred across a logging road upslope. Water courses higher on the mountain were diverted to this breach by continued erosion. $B$, A view of the same slide area, looking upslope, from U.S. Route 4 a year later. The artificial drainage structures blend in well with the natural drainage.

The instrumentation was used to determine the rates of movement on discontinuities, such as joints, and the mechanisms that control these movements (Baskerville and others, 1988; Lee, 1989). We also sampled many of the rocks for chemical analysis to determine which major oxides were in the various rocks and in what percentages. These data, along with petrographic study, helped in the determination of the susceptibility of a particular rock unit to decomposition, especially along discontinuities.

\section{MOVEMENTS OF SOIL MATERIALS ON SLOPES}

\section{Soil Types in Vermont}

Residual soils, which commonly form over bedrock in situ by a long period of chemical decomposition, are uncommon in Vermont. Instead, many soils in Vermont are the result of glacial transport and deposition and are generally unrelated to the underlying bedrock (Doll and others, 1961; 1970). Glacial tills that are quite compact underlie many stream valleys throughout the State. Some areas such as in the granitic terrains of northeastern Vermont contain clean ablation tills. These are loosely

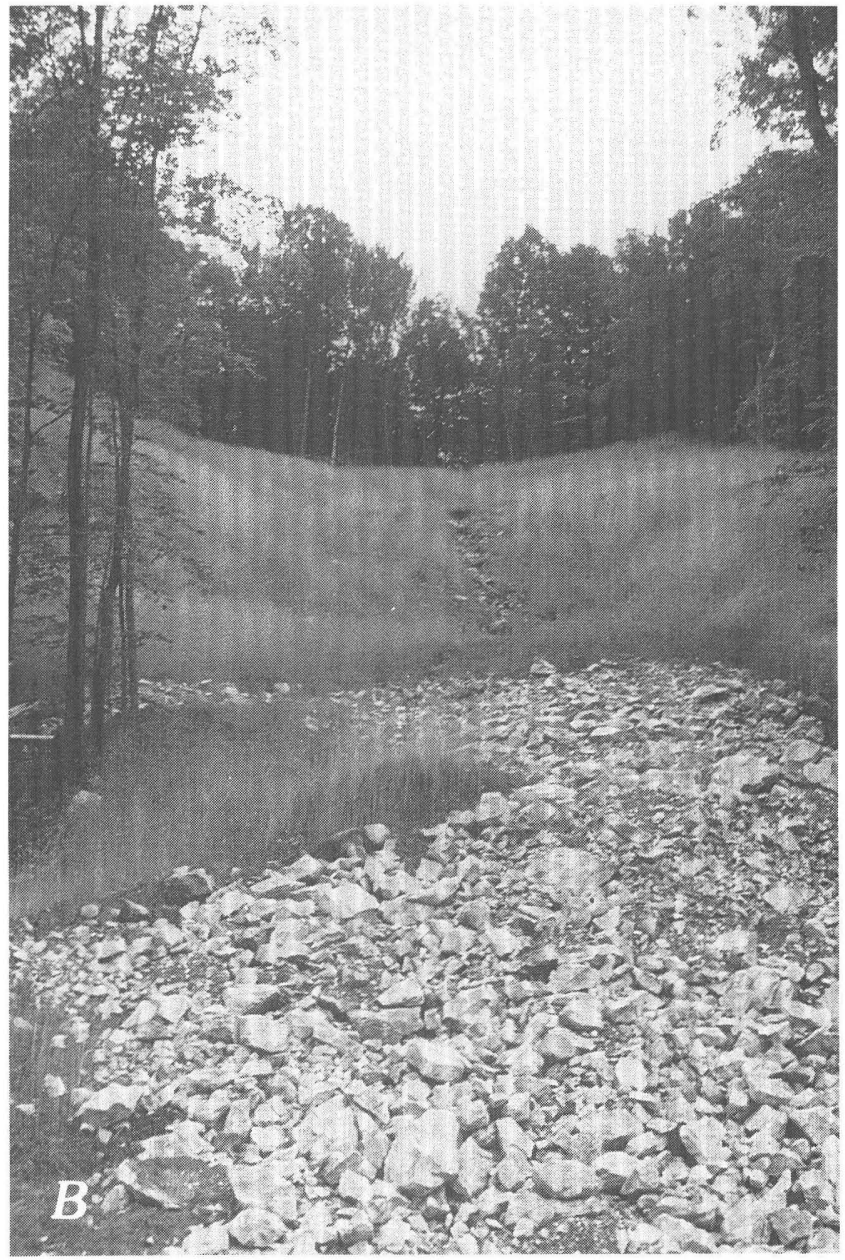

combined glacial rock material that has been winnowed of fines as the ice disappeared by ablation and evaporation in place. Other glacial deposits are kames and thick till deposits, both of which form terraces in many river valleys. All of these sediments are stratified, being crossbedded if formed in deltas or rhythmitic units if formed in glacial lakes (fig. 5). Rhythmites are cyclical deposits composed of fine sands, silts, and clays (Bates and Jackson, 1980).

\section{Types of Soils in which Slope Movements Occur in Vermont}

As the continental glaciers retreated during the late Pleistocene, the meltwaters formed ice-marginal lakes (Hamblin, 1989). Various sedimentary deposits are associated with these lakes, such as varves, rhythmites, and deltas. Some glacial lake deposits are prime examples of potentially unstable materials. Typically, the stratigraphic section where rhythmitic sediments occur contains thick deposits of crossbedded deltaic sands and fine gravel overlying the rhythmite unit of alternating beds of silt and clayey silt. The rhythmite sequence generally overlies a coarse gravel and boulder ablation till or kame deposit. The 


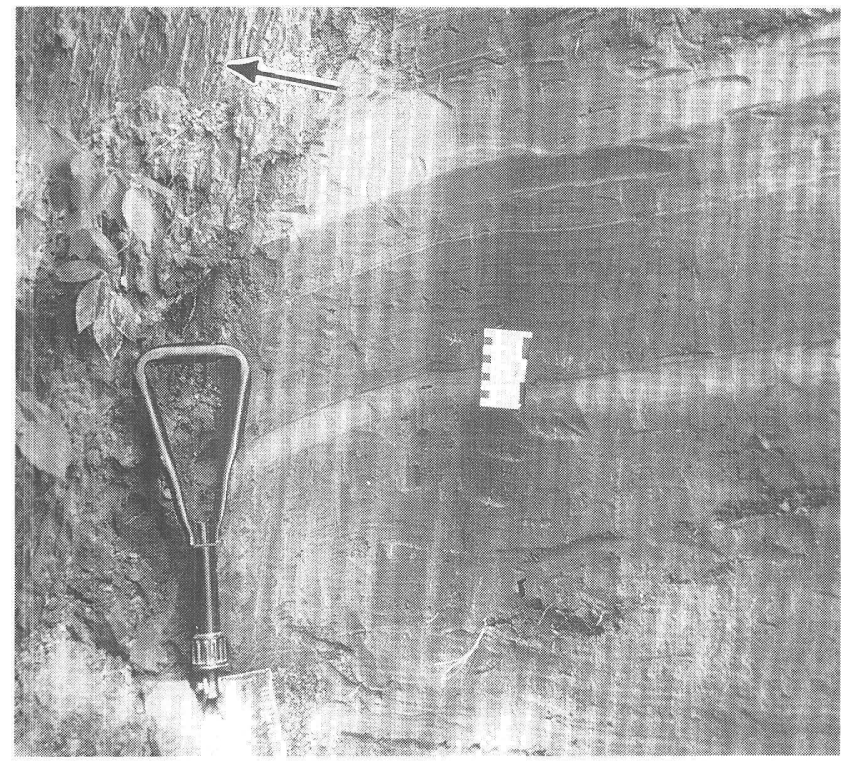

Figure 5. Rhythmite sequence at North Springfield floodcontrol reservoir. Slickensides (arrow) from where the material slid on the scarp can be seen in the extreme upper left.

top of the entire sequence may or may not have a cap of Holocene colluvium (fig. 6).

Such soil profiles as described above are present along terraces in many Connecticut River basin stream valleys in Vermont, such as the Black River valley along Vermont Route 11 in Springfield and the White River valley along Vermont Route 14 near Sharon (Baskerville and Ohlmacher, 1988). Springs fed by base flow from streams on terrace surfaces can lead to failures by increasing the pore-water pressure in the less clayey layers of rhythmites. Increased pore-water pressure reduces effective normal stress and triggers slope failures. This was the failure mechanism on Vermont Route 11 in Springfield (Baskerville and Ohlmacher, 1988). Where these terraces occur within reservoirs, failure can develop during rapid drawdown of reservoir water. In this process, the rapid drawdown suddenly lowers the water to normal pool level and leaves the water table perched high in the reservoir slopes. The saturated slopes begin to fail initially in the rhythmites, aided by the differential pore-water pressures in the silt and clayey silt layers. These conditions developed in 1984 over extensive areas of the perimeters of the reservoirs of the North Springfield and the North Hartland flood-control dams (Baskerville and Ohlmacher, 1988).

High pore-water pressure caused by prolonged precipitation helps to generate sliding in glacial lakebed terrace deposits. These deposits almost always have a rhythmite unit 2.4 or more meters thick in the upper one-third of the terrace. Clayey layers that alternate with coarser silt layers in these rhythmites prevent rapid infiltration of heavy precipitation. Increases in pore-water

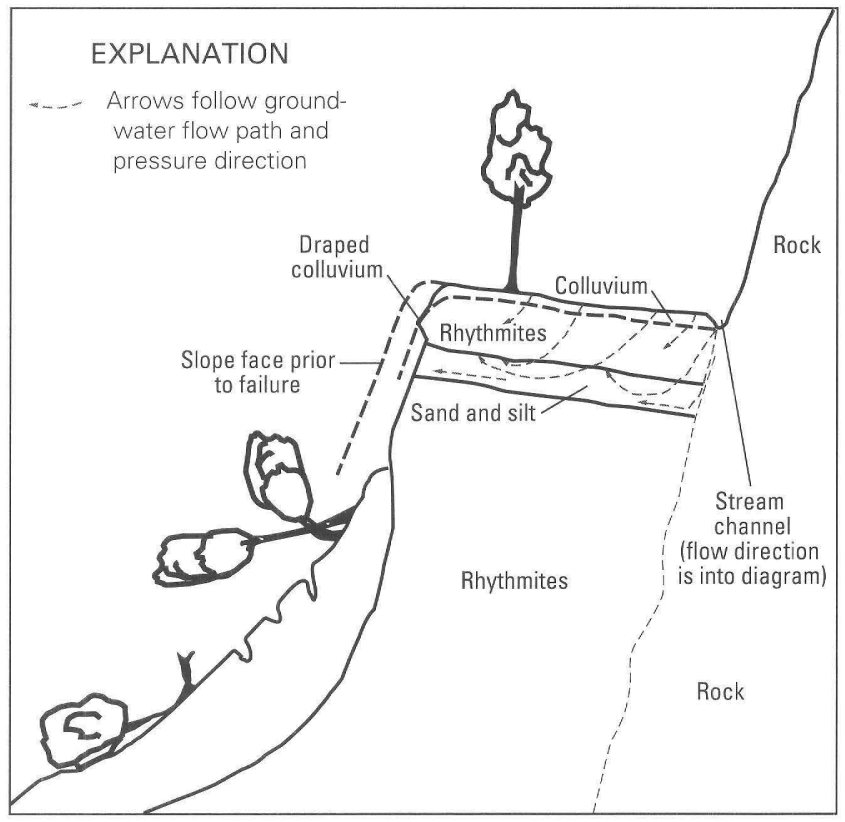

Figure 6. A typical rhythmite sequence. Streams often cut channels parallel to the rock wall. The water feeds into the more permeable layers, approximately following the baseflow vector arrows shown, and thus increases pore-water pressure. Slope failures are triggered because effective normal stress is reduced by the increased pore water.

pressure occur in two places: at the contact of the rhythmite with overlying crossbedded deltaic or colluvial deposits and in the silt and fine sand layers within the rhythmite.

Deposits of basal till along streambanks are also subject to slope movement by both bank undercutting and saturation of the clay-rich components. When these clays become saturated, the basal portion of the mass becomes fluidized and sets the stage for sliding (Ohlmacher and Baskerville, 1991). Till is a heterogenous mixture of boulders, gravel, and sand-sized material in a matrix of clayey silt. It generally is very dense and has a relatively high shear strength. The types of failures in till range from block slides to earth flows. These types of slope failures are frequent in the Clay Brook and Mill Brook Valleys near Warren (site 2, fig. 3). Similar failures occur along Brook and Holbrook Hill Roads between Hartland Four Corners and Brownsville in the town of West Windsor (sites 4 and 24, fig. 3).

An example of a naturally occurring slide in such tills is in the town of West Windsor (site 4, fig. 3). These compact tills have very high shear strength. Natural moisture content, 5 percent or less in these deposits, is so low as to make them almost dry. The clayey silt matrix has its shear strength reduced drastically when saturated (Baskerville and Ohlmacher, 1988; Ohlmacher and Baskerville, 1991).

Some soil deposits are on steeply dipping bedrock slopes. Heavy prolonged rainfall causes high pore-water 
pressures that trigger sliding on bedrock surfaces (see table 1 in Baskerville and Ohlmacher, 1988). The deposits on Brook Road are an example of this. Ohlmacher and Baskerville (1991) have determined that high clay content of these soil masses is not a prerequisite for movement; water pressure buildup in the pores of fine sand and silt layers restricted by less permeable layers appears to be the primary triggering mechanism.

\section{Natural and Human-Induced Slope Movements in Vermont Soils}

Natural slope failures in Vermont are often triggered by abnormally intense and prolonged rainfall. In the spring, snowmelt adds to the problem by presaturating the soil (Baskerville and Ohlmacher, 1988; Baskerville, 1990). These conditions also aid in the creation of torrential streamflows that undercut banks and cause instability (Baskerville, 1990). Storms and high water levels have combined to cause coastal erosion and some slope failures on the Vermont shore of Lake Champlain. Along the lakeshore, Vermont Route 125 near Chimney Point State Park and the Blake Lawrence estate near Vergennes (fig. 7), are examples of this.

Some of the human-induced slope instabilities are related to logging practices, such as clearcutting on some slopes, or to poor maintenance and abandonment of logging roads. Examples of these failures are near Hardwick and in Mendon (fig. 4A). In the case of the Hardwick slide, at least 150 ha (hectares) were clearcut. This site is in the Lamoille River valley. It appears that without the forest cover for protection, heavy precipitation was able to infiltrate and saturate a rhythmic substrate that is composed of clayey silt alternating with more clay-rich layers.

Ritter (1986) indicated that as much as 50 percent of the precipitation is intercepted by a forest canopy. Without a canopy, the added water at Hardwick infiltrated into the ground and created a saturated fluidlike zone upon which a massive movement of the entire tract occurred, similar to slides at North Springfield (Ohlmacher and Baskerville, 1991).

Following the 1984 failure, the Hardwick site had an extremely heavy rate of runoff that was concentrated into channels that were about $1 \mathrm{~m}$ wide and deep. Additionally, tension fractures both surrounded and crosscut the slide mass. On August 2, 1984, vane shear tests were taken on the scarp faces of some of the fracture zones. Torvane tests gave maximum shear strength values of $49 \mathrm{kN} / \mathrm{m}^{2}$ (kilonewtons per square meter), indicating a low-strength material. On July 31, 1985, Shelby tube samples (VT-10 and VT-11) were obtained from substrate material in a tension fracture. The material at the very base was wet but too thin to sample; the estimated unconfined compressive strength of this material is approximately $20 \mathrm{kN} / \mathrm{m}^{2}$ (see

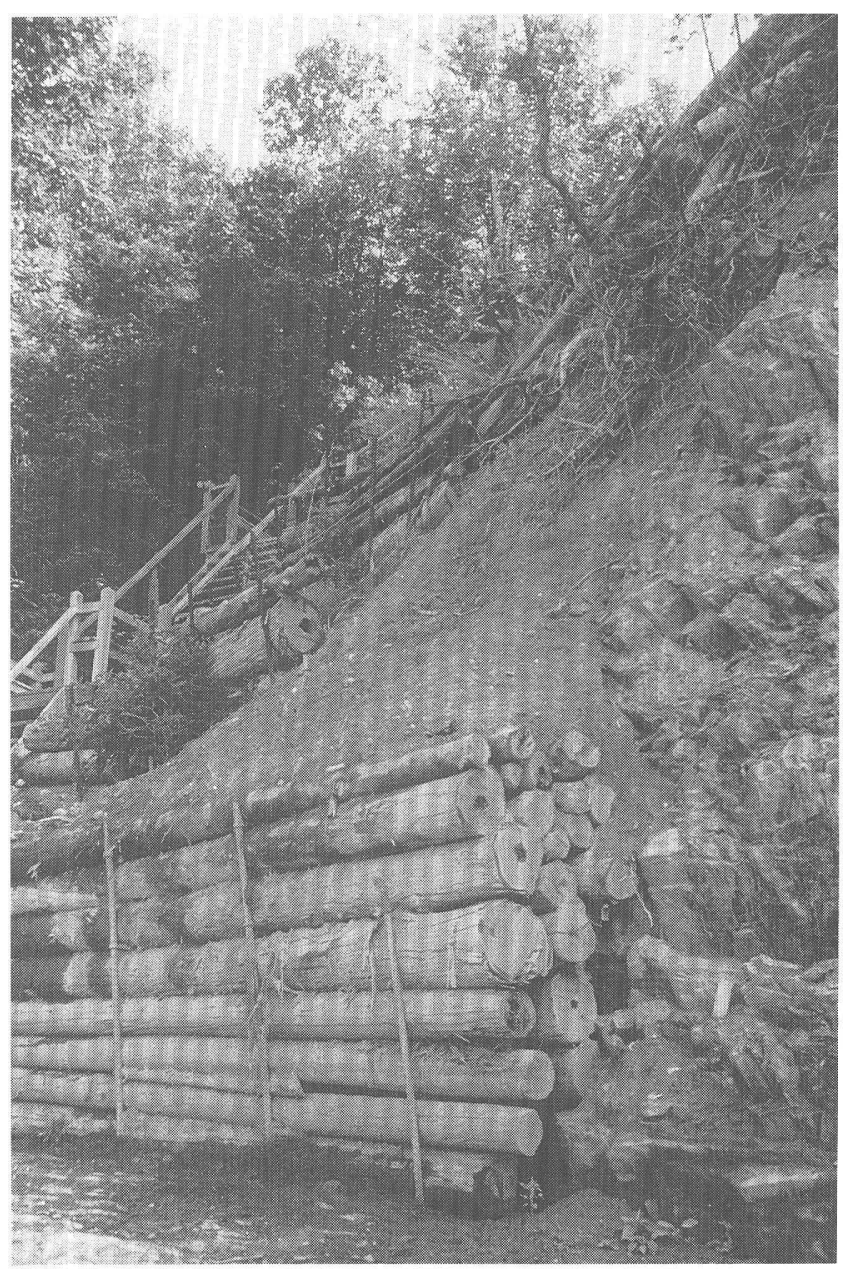

Figure 7. Shoreline slope failure on Lake Champlain near Vergennes. Both soil and bedrock failed. The timber cribbing has been placed in an attempt toward stemming further failures.

table 2:6 in Sowers, 1979). Torvane and penetrometer (unconfined shear strength) tests gave results of 354 to 462 $\mathrm{kN} / \mathrm{m}^{2}$ and 216 to $236 \mathrm{kN} / \mathrm{m}^{2}$, respectively. These results show that these slide materials have relatively high strength when drained.

Examination of the undisturbed samples showed that this substrate material contained no coarse particles such as pebbles. The undisturbed samples also showed many large, jagged, primary void spaces; most of these spaces were oriented normal to the axis of the cylindrical soil samples. These void spaces appear to be pull-apart tension fractures spaced a few centimeters apart, possibly a result of ground movement.

Results from unconfined uniaxial compression tests on samples VT-10 and VT-11 indicate that, without saturation, this section has a reasonably high strength. If the total precipitation falls directly on the soil without the intervention of vegetation, surface runoff and infiltration 
will become the only methods of water dissipation and will help to decrease soil strength.

The 1984 Mendon slide was generated following erosion of a logging road high upslope on East Mountain. This road was built to haul logs and carry drainage east or west to existing stream channels and off the mountain. Through time, without maintenance, this road developed a transverse breach that allowed the drainage to develop a new channel. This new channel ran directly downslope, and subsequently a debris flow developed along this new track (Baskerville and Ohlmacher, 1988; fig. 4).

Another example of human-induced sliding developed in Topsham at the upper end of Powder Spring Brook valley (site 7 , fig. 3). The slide mass measured $40 \mathrm{~m}$ in length and $23 \mathrm{~m}$ in width at about midlength. The slope angle was $37^{\circ}$. At one time, the toe area of the slide was a source of soil borrow. The excavation of the pit destabilized the slope above. During a series of heavy rains, which supplied excess pore pressure, the slope above the pit face failed.

Clearcutting and poor maintenance are not the only causes of human-induced slope failures. Other causes are overly steep cut slopes and slopes cut where the bedding or foliation of rock dips toward the roadway.

\section{Differing Rates of Movement in Soils in Vermont}

Free-draining coarse materials may present slope stability problems as exemplified on the south side of Vermont Route 9 near Woodford, just east of Bennington (fig. 3). At the Woodford site, the slope contains glacial deposits composed mostly of coarse quartzite. These deposits range from gravels to boulders on a slope that stands about 60 to $90 \mathrm{~m}$ higher than the road. This slope continually shows signs of creep or landslide movement, particularly in wet weather.

An initially slow-moving slide occurred near Vermont Route 9 on Whetstone Brook near Marlboro (site 26, fig. 3). Heaving played a part in the slow slope motion of the Whetstone Brook slide. Heaving is usually an integral part of creep motion on slopes in that the forces disrupting the mass operate by expansion normal to the surface (Ritter, 1986). This greatly facilitates gravitational motion downslope. The headscarp at the top of the Whetstone Brook slide measured $12 \mathrm{~m}$ in height, and the slide surface contained disrupted vegetation. Anecdotal evidence from the auto repair garage owners across the brook from the slide suggests that small annual movement of the mass has been occurring since 1971. Examples of slides that slowed to creeping movement occurred in Mill Brook valley west of Irasville (site 27, fig. 3). Trees on some slopes of the brook exhibit a pipestem structure, which is a curvature at the base of the tree trunks. These pipestem structures suggest that the slope had initially undergone a rapid

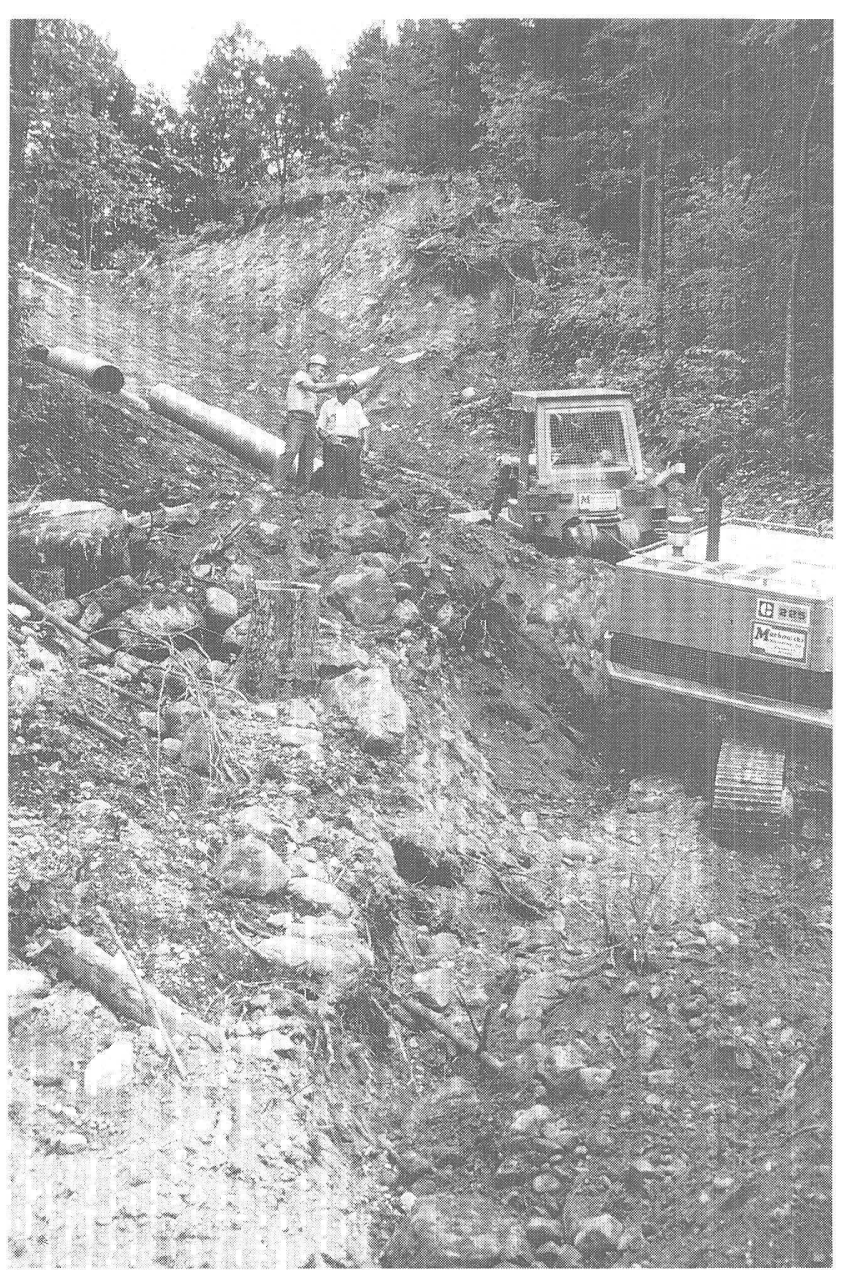

Figure 8. Slide being repaired on East Mountain, Mendon. The slide chute has carried debris onto U.S. Route 4 several times. Regrading and the placement of drains to move excess water flow have mitigated the danger associated with this slide.

translational slide, which tilted the trees downslope. Later, the movement slowed enough for tree trunks to realign vertically toward sunlight.

Examples of rapidly moving flow slides are those that have occurred in glacial till on the north slope of East Mountain on U.S. Route 4 east of Rutland (fig. 3). At one of the East Mountain sites, a large slide recurred in the spring of 1983 (fig. 4A). This debris flow developed after heavy spring rains and completely blocked U.S. Route 4. Fortunately, no vehicles were passing the site at the moment of this event. Records show that damage was restricted to the highway and adjacent property. The Vermont Agency of Transportation has alleviated this problem by installing drains to reduce the water pressure in the slope. The slide chute was also lined with large riprap to prevent further erosive degradation of the channel (figs. $4 B$ and 8).

Extremely rapid slide and flow movements can exceed $3 \mathrm{~m} / \mathrm{s}$ (Varnes, 1978). The Dorset Mountain debris avalanches in north-central Bennington County (see site 6, 


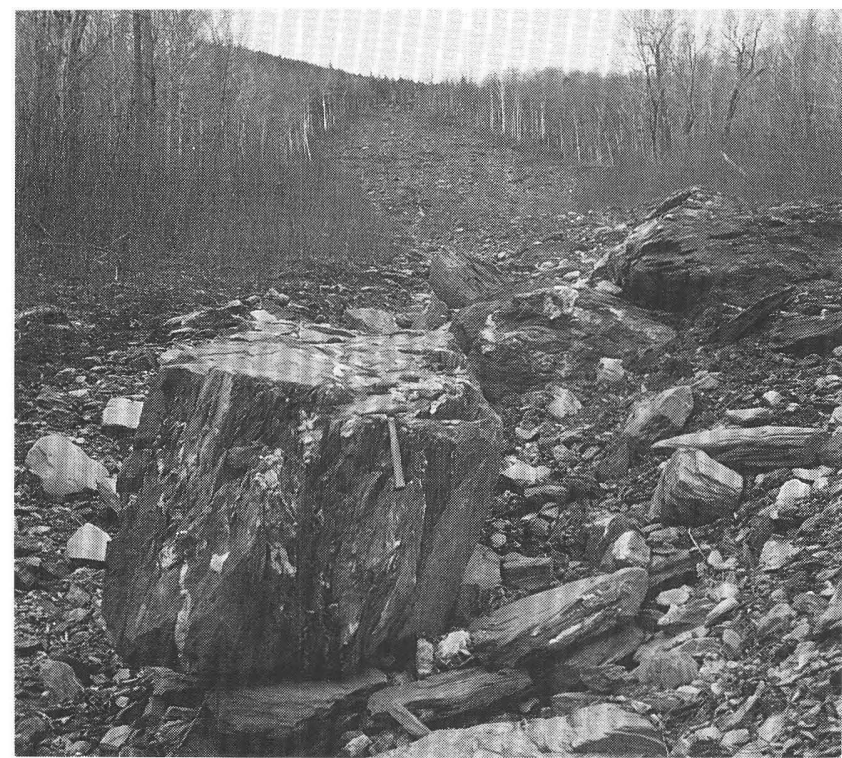

Figure 9. Debris avalanche scar from failure on August 10, 1976, on Dorset Mountain. This was one of at least four separate landslides that occurred on the south-facing slopes of this mountain (site 6, fig. 13). Several thousand cubic meters of soil, detached joint blocks of rock, and at least 40 ha of trees rushed downslope along runout paths up to $4.2 \mathrm{~km}$ in length. These slope failures were preceded by several days of rain that culminated in a heavy cloudburst (Ratté and Rhodes, 1981).

fig. 13) of 1976 illustrates high-velocity flows. This avalanche covered a distance of $3 \mathrm{~km}$ in less than $5 \mathrm{~min}$ traveling at an average rate of $10 \mathrm{~m} / \mathrm{s}$. Four almost simultaneous debris avalanches from Dorset Mountain destroyed 40 ha of trees (Ratté and Rhodes, 1981).

\section{Debris Avalanches}

Debris avalanches are long, narrow slope failures made up of masses of bedrock, soil, and, in some instances, trees that flow downslope (fig. 9). Failure is sudden, and the debris avalanche rapidly gains momentum, adding mass during its descent. This type of mass movement is relatively common in western Vermont, where many scars attest to their occurrence. Of the various types of rock-slope failures recognized in Vermont, debris avalanches are by far the most destructive to forests, roads, and streams. Debris avalanches obviously have a potential for causing considerable damage to mountainside developments. Field studies have identified several conditions that favor the initiation of a debris avalanche. Foliated metamorphic rocks, mainly chlorite-muscovite phyllites and fine-grained schists, are the predominant rock types associated with these failures. The foliation of these rocks when related to failures is typically horizontal or has gentle dips down toward the roadway. Well-developed, open, vertical joint sets strike about parallel and perpendicular to the axes of debris chutes in and next to the headwalls. These joints truncate foliation surfaces, and the result is a zone of loosened blocks that average $1 \mathrm{~m}$ in thickness. Soil cover is thin to nonexistent on upper slopes next to slide chutes and increases to $1 \mathrm{~m}$ in thickness midway down the slope. Bedrock, where exposed in the avalanche scars, is fresh, and joints are closed. Headwalls of debris avalanches are formed as steep $\left(40^{\circ}\right.$ to $\left.90^{\circ}\right)$, south-facing cliffs or benches located below flatter, more stable mountaintops. The middle and lower portions of debris avalanches have concave-outward topography suggesting that they may occupy old drainage paths that are perhaps related to the foliation. Vertical drops of over $600 \mathrm{~m}$ and slide chute lengths of more than $3 \mathrm{~km}$ are on record (Ratté and Rhodes, 1981). Avalanche debris contains abundant angular blocks of fresh bedrock having a wide range of sizes. Historical records give a sense of the weather conditions before a failure. Typically, several days of rain culminate in an intense local downpour of 6 to $8 \mathrm{~cm}$ of rain in 3 to 4 hours. This type of storm occurs most frequently in the late spring and summer months. This timing coincides with many documented debris avalanches such as at Mt. Greylock in western Massachusetts, in the eastern Adirondacks of New York, and at other places in eastern North America (Eschner and Patric, 1982).

A vivid account of a debris avalanche that occurred on June 27, 1827, near Waitsfield in Washington County (fig. 3), was given by Theron Baldwin (Baldwin, 1829, p. 228-232):

On the 30th of June, I went, in company with sixteen of my neighbors, to visit the spot so singularly marked by Providence, which I am now about to describe. I found the slide to commence near the top of the mountain, between two large rocks which were stripped of earth, opening a passage of four rods wide, from it proceeded in a south easterly direction, gradually widening for a distance of two hundred rods, to the south branch of Mill Brook in Fayston. In its course it swept every thing in its way; overturning trees by their roots, divesting them of roots, branches and bark, and often breaking them in short pieces. A number of rocks, judged to weigh from fifteen to twenty tons were moved some distance. From where it entered Mill Brook, its course was in a north easterly direction, two hundred and eighty rods, the natural course of the brook being very small; but the channel cut by this torrent is now from two to ten rods in width; and on either side are large quantities of flood wood piled up very high; and from fifteen to twenty rods of the lower part it is blocked up across the channel in every direction; some of the trees are standing on their tops, and generally stripped of roots, branches and bark, and broken into many 
pieces. The pile in some places is ten feet high. Much of the timber is apparently buried several feet in sand and mud. One large tree was broken off square, measuring three feet nine inches where it was broken. One black ash was literally pounded into a broom, whose brush is seven feet long. The whole distance of these ravages, is a mile and a half, and the quantity of land thus suddenly metamorphosed into a barren waste, is twenty five acres. The force of water must have been very great, at which, we cannot wonder, when we consider its probable depth. In some places, from appearances, it must have been thirty or forty feet high, and there was mud on them at that height. Heavy rains for several days preceded this debris avalanche, which produced a roar that could be heard for miles, and was thought by some to be an earthquake or a clap of thunder.

The preceding description is probably accurate because the effects of similar destructive slope movements were seen by the authors on Dorset Mountain (see fig. 13) where a debris avalanche occurred after several days of rainfall on August 10, 1976. These rains culminated in a cloudburst that produced 8 to $10 \mathrm{~cm}$ of rainfall in a 24-hour period (Ratté and Rhodes, 1981). Similar conditions have quite likely occurred at many times and places in the past.

\section{Slope Remediation}

When development on relatively steep slopes cannot be avoided, priority should be set on a determination of the potential for movement by analysis of the types of materials composing the slopes. Materials encountered at construction sites should be sampled, and their laboratory and engineering characteristics should be determined.

Studies of natural drainage systems are needed at new construction sites. These studies will determine the slide susceptibility of materials; susceptible materials can then be prevented from becoming saturated and losing shear strength. Artificial drainages associated with construction should complement the natural drainage so that conditions for a potential slope failure do not develop.

Some slopes may have a history of intermittent creep, such as those along streambanks where the trees show pipestem structures. These streambank slopes may be in equilibrium because of their vegetative cover. If a determination is made to develop such slopes, it is imperative that the project not disturb the existing vegetation. Artificial drainage installed during construction must be properly maintained afterward. As much vegetation as possible should be replaced after construction so a change in surface-water runoff and infiltration regimes can be prevented (Greenway and others, 1984). Changes in the surface-water regime also affect the subsurface water table. When both the surface and subsurface water regimes are altered, slope failure can result.

Several slope failures have occurred in the Castleton River valley between Castleton and Rutland as a result of construction in the 1980's. Two shallow slides occurred on new U.S. Route 4 while construction was in progress. A complex slide developed on old Route 4A to the west of those cited on new Route 4 (site 28, fig. 3). One of the U.S. Route 4 slides occurred in 1985 during construction of a cut slope on the section between West Rutland and U.S. Route 7 south of Rutland. In these cases, overconsolidated slope materials (basal tills) failed. These tills became unstable when saturated. The slopes of $26^{\circ}$ or more failed in both rotation and translation.

In applying corrective procedures to the landslide at Mendon, the placement of artificial drainage structures complemented the natural drainage. These corrective procedures on East Mountain have worked very well (fig. $4 B)$.

Regrading to a flatter slope has been a remediation strategy used in Vermont on failed slopes. Other measures include installation of vertical and horizontal drains in slopes to relieve the buildup of pore-water pressures, and the placing of a heavy stone or massive concrete block berm on the toe of slopes to prevent further movement. Many failed slopes are beyond rehabilitation without very high costs. Sometimes, even after the remedial efforts, the results are not permanent.

The U.S. Army Corps of Engineers regraded and revegetated as remedial steps for failed slopes in the North Springfield flood control reservoir. Subsequently, high water levels in the reservoir generated further failures on some of these repaired slopes (Baskerville and Ohlmacher, 1988).

Adding riprap to the toes of failed slopes can stabilize highway cut slopes in soils (fig. 10). Riprap was added as bank protection for a house on Andover Brook west of Chester (fig. 11). Such steps aid in preventing headward continuation of failure in stream channels, although there is no guarantee that failure will not occur on adjacent channel ground.

A debris flow occurred just south of Windsor during heavy rains in May 1984 on U.S. Route 5 and blocked the highway (Baskerville and Ohlmacher, 1988). The Agency of Transportation placed a heavy stone counterweight berm along the toe of the slope to try to prevent a future landslide. The intent of this berm is to stabilize the toe of the slope and prevent further slope movement.

Perforated vertical corrugated drain is also used to lower the soil pore pressure (fig. 12). This procedure reduces the potential for sliding on a slope composed of glacial till on Killington Mountain (site 30, fig. 3). Slope failures occurred in tills along the East Creek and Ottauquechee River drainage basins, on East (site 15, fig. 3) and Killington Mountains, respectively. Systems of horizontal 


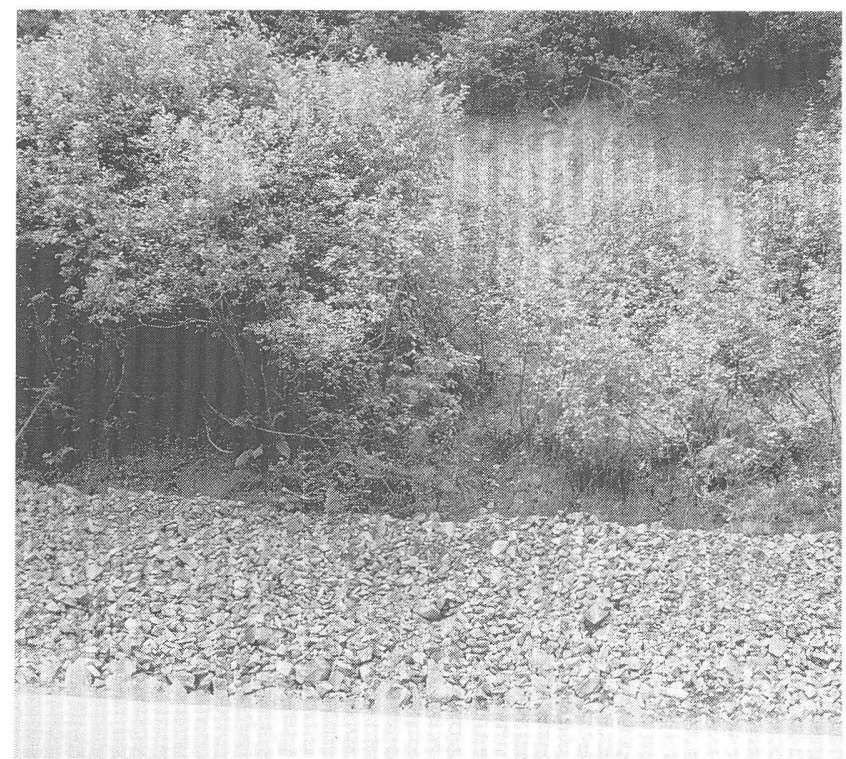

Figure 10. Riprap berm used to add weight to the toe of slope on a road shoulder after a slide west of Bridgewater Corners on U.S. Route 4 . This procedure is used as an aid toward preventing further movement.

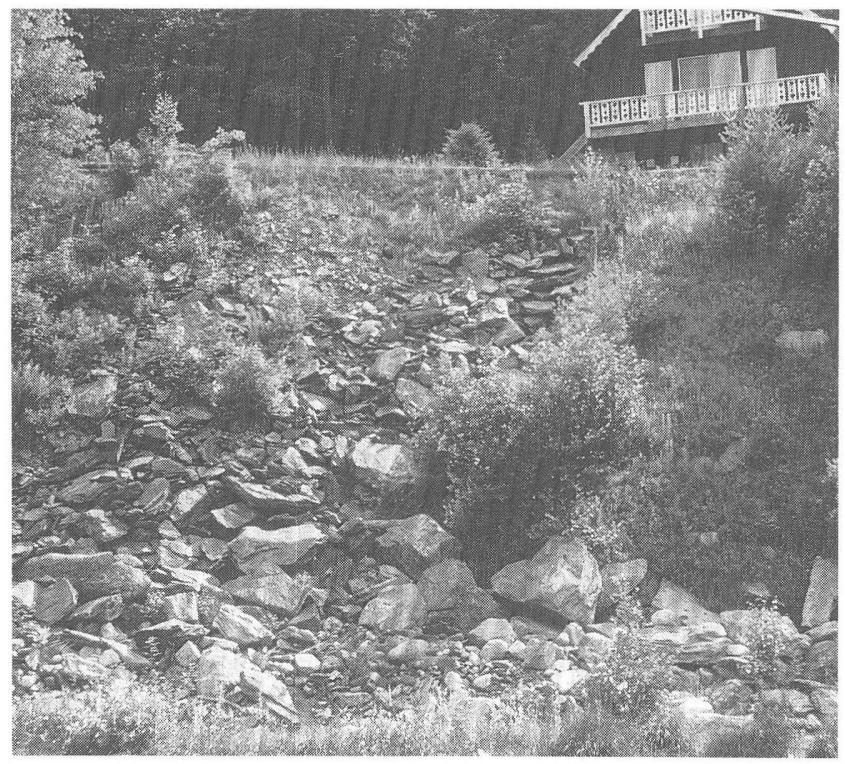

Figure 11. The Andover Brook has undercut its bank in front of this house. Riprap has been placed on the slope in the hope that future undercutting and loss of the house will be prevented.

and vertical drains placed in these slopes are effective methods for reducing further movement. This procedure was developed in Japan (Hoek and Bray, 1977; Yamaguchi, 1980).

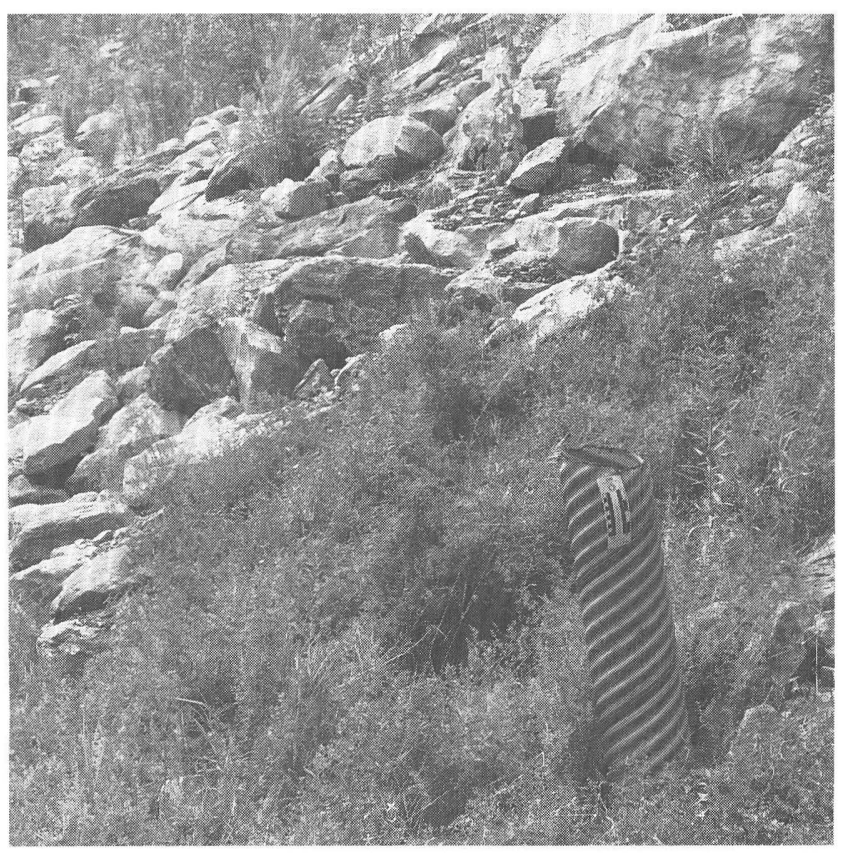

Figure 12. Corrugated vertical drain used at Killington Mountain. This device helps to lower water pressure in the slope so as to reduce sliding potential. Horizontal drains farther downslope, connected to the bottom of the vertical drains, carry the excess water out of the slope.

\section{SLOPE MOVEMENTS IN BEDROCK}

In this report, bedrock denotes consolidated earth material that underlies unconsolidated or soillike materials. Bedrock is not necessarily strong or durable. On the other hand, the strength and deformation properties of bedrock commonly far exceed those of soils or glacial deposits.

Soil cover in the mountainous parts of Vermont is typically very thin, particularly at higher elevations. Bedrock, or ledge, in various parts of the State differs considerably in hardness, color, grain size, and mineral composition. However, these properties are not the most significant in an analysis of the stability of rock slopes in Vermont.

\section{Conditions that Promote Rock-Slope Movement}

As noted by Piteau (1970), the basic parameters of interest in understanding rock-slope behavior are (1) the systems of joints and other discontinuities, (2) the relationship of discontinuities to potential failure surfaces, and (3) the strength parameters of discontinuities, which include properties of both the joint surface and any infilling material. Besides the intrinsic features of the rock mass, several external factors are important for analyzing rockslope stability. The most important of these are precipitation, freeze-thaw cycling, and earthquakes. Precipitation is critical because additional water may 
Table 1. Types of discontinuities in rock causing failure of slopes

[Definitions are from the American Geological Institute's Glossary of Geology (Gary and others, 1972)]

\begin{tabular}{|c|c|}
\hline \multicolumn{2}{|c|}{$\begin{array}{l}\text { Joint ............ A surface of actual or potential fracture or } \\
\text { parting in a rock, without displace- } \\
\text { ment; the surface is usually planar and } \\
\text { often occurs with parallel joints to } \\
\text { form part of a joint set. }\end{array}$} \\
\hline Tension joint .... & . A joint that is a tension fracture. \\
\hline Shear joint ..... & $\begin{array}{l}\text { A joint that is a shear fracture; a potential } \\
\text { plane of shear. }\end{array}$ \\
\hline Sheeting structure. & $\begin{array}{l}\text {. The type of fracture or jointing formed by } \\
\text { pressure-release jointing or exfolia- } \\
\text { tion. }\end{array}$ \\
\hline Fault........... & $\begin{array}{l}\text {. A surface or zone of rock fracture along } \\
\text { which there has been displacement, } \\
\text { from a few centimeters to a few } \\
\text { kilometers in scale. }\end{array}$ \\
\hline Shear zone..... & $\begin{array}{l}\text {. A tabular zone of rock that has been } \\
\text { crushed and brecciated by many parallel } \\
\text { fractures due to shear strain. }\end{array}$ \\
\hline Bedding surface .. & $\begin{array}{l}\text {.A surface, usually conspicuous, within a } \\
\text { mass of stratified rock, representing an } \\
\text { original surface of deposition; the sur- } \\
\text { face of separation or interface between } \\
\text { two adjacent beds of sedimentary rock. } \\
\text { If the surface is more or less regular or } \\
\text { nearly planar, it is called a bedding } \\
\text { plane. }\end{array}$ \\
\hline Foliation . . & $\begin{array}{l}\text { A general term for a planar arrangement } \\
\text { of textural or structural features in any } \\
\text { type of rock. Cleavage in slate or } \\
\text { schistosity in a metamorphic rock, for } \\
\text { example. }\end{array}$ \\
\hline
\end{tabular}

increase hydrostatic pressures on the joints and thus decrease stability. Freeze-thaw is known to have displaced joint blocks in the Green Mountains and as a result to have caused rockfalls (Lee, 1989). Earthquakes have triggered landslides in many parts of the world and are responsible for much damage annually; however, in Vermont earthquakes are infrequent and mild, so this cause of slope failure is rare.

\section{Types of Structural Discontinuities in Rock}

The term "discontinuity" is applied to those geologic structural features, such as joints, faults, and bedding surfaces, that divide the rock mass into individual blocks. Researchers in many countries agree that most failures of rock slopes are controlled by such geologic structures (Schuster and others, 1975; Goodman, 1976; Tharp, 1984). A list of types of discontinuities in rock-slope studies and their definitions is given in table 1. Terzaghi (1962) demonstrated the function and importance of discontinuities to the maintenance of stable slopes. Terzaghi calculated the critical height, $H_{c}$, of a vertical cliff of relatively weak, intact (free of discontinuities) rock as being approximately $1,290 \mathrm{~m}:$

$$
H_{c}=\frac{q_{u}}{\gamma}=1,290
$$

where the unconfined compressive strength, $q_{u},=34.5$ MPa and the unit weight, $\gamma$, is $2,720 \mathrm{~kg} / \mathrm{m}^{3} \times 9.8 \mathrm{~m} / \mathrm{s}^{2}$. Even for stronger, intact hard rocks such as granite, no vertical faces as high as $1,290 \mathrm{~m}$ have been found. Countless numbers of nonvertical slopes of much lesser height have failed. Therefore, the critical height of rock slopes is largely related to the structural discontinuities of the rock and not the strength of the rock itself. In contrast, the slope behavior of soils, and especially of relatively soft soils, depends upon the properties of the intact soil almost independent of discontinuities in the soil. In hard rock, the path of failure follows preexisting surfaces or zones of weakness, and such is the case for rock-slope failure in Vermont.

\section{ROCK-SLOPE MOVEMENT TYPES}

Rock-slope movements in Vermont are mainly rockfalls, rock avalanches, block slides, and topples. Combinations of these failure modes occur at some locations. Representative of all the types of movement mentioned above, figure 13 shows the locations of several rock-slope movements in western Vermont.

\section{Rockfall}

In rockfall, a detached rock mass falls from a steep slope or cliff. Blocks of rock can fall, bounce, and roll down the slope, as shown in figure 14. Falls are the most rapid type of rock-slope movement, although they are usually preceded by minor movements leading to progressive separation of blocks from the main mass. Rockfalls account for the smallest volumes of rock of any of the major kinds of rock-slope movements in Vermont. While they typically occur in the upper, steeper slopes of mountain ranges, they also occur on steep slopes at lower elevations (sites 1, 3, and 5, fig. 13). On July 13, 1983, in a rockfall at Smugglers Notch, one or more blocks of schist fell that are estimated to have weighed more than 10,000 tons. The joint surfaces that bordered these blocks may have acted as conduits for water. The cumulative effects of repeated freezing and hydrostatic pressure caused block displacements leading to the instability of this cantilevered overhanging mass (Baskerville and others, 1988). This rock bounded upon loose rock, soil, and vegetation and triggered a debris slide. There are many such unstable blocks in this part of the Green Mountains. In 1910, a block called King Rock dislodged from a high valley wall in Smugglers Notch 


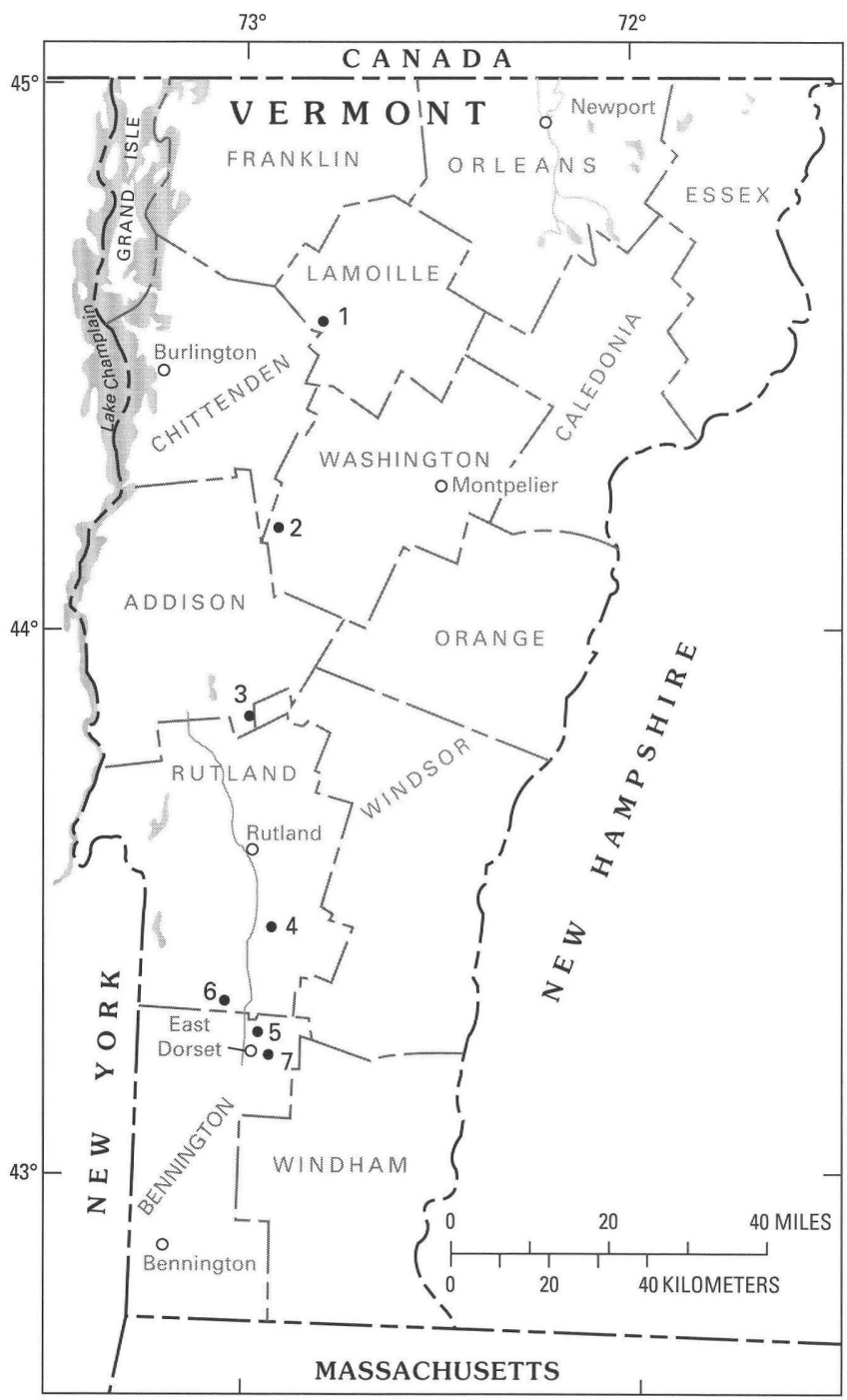

Figure 13. Locations of some rock-slope movements in western Vermont. Numbers indicate sites referred to in the text: 1, Smugglers Notch; 2, Mill Brook; 3, Mount Horrid; 4, White Rocks Recreation Area; 5, Mount Tabor; 6, Dorset Mountain; 7, Mad Tom Brook.

and tumbled intact to the valley floor. King Rock has an estimated weight of 6,000 tons (fig. 15). Some rockfalls that occur during periods of heavy rain may fall or tumble onto saturated soil and unconsolidated glacial deposits and trigger a debris avalanche. Curiously, the 1983 Smugglers Notch event occurred during a relatively dry period.

\section{Block Slides}

Block slides are commonly controlled by defined joints that are usually at some large angle to bedding or foliation surfaces. These slides occur on slopes that are close to the angle of stability for the particular block of rock (for quartzite, this is $45^{\circ}$ to $60^{\circ}$ ). If blocks slide over a step

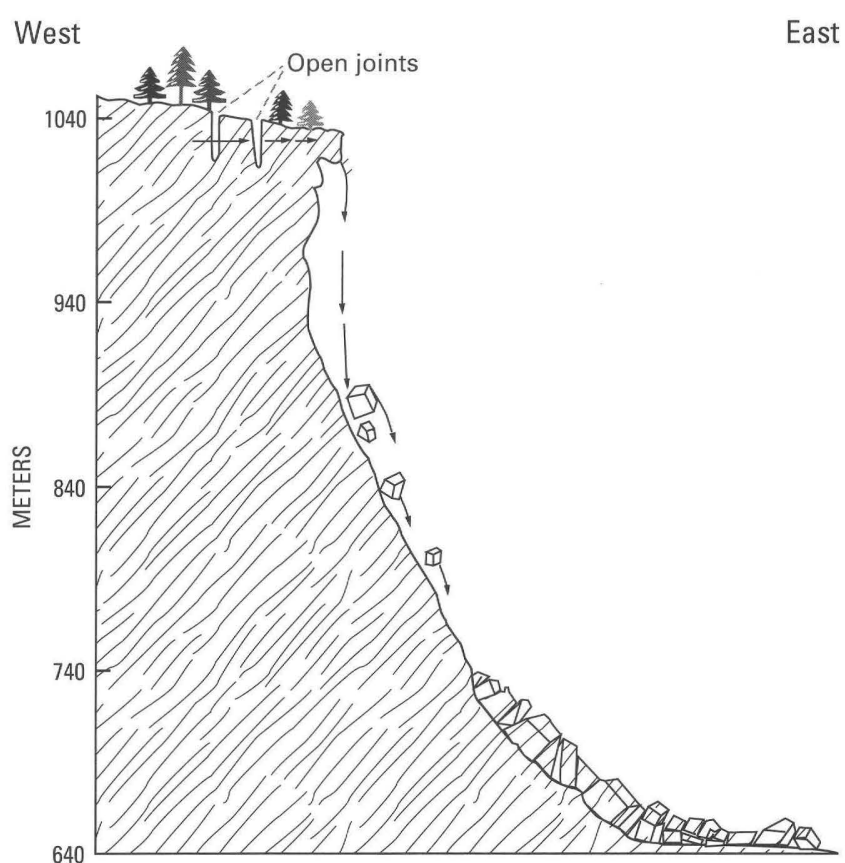

Figure 14. Generalized section through Smugglers Notch (site 1, fig. 13) showing rockfalls and debris accumulation at the base of the slope. The open joints observed at several locations at the top of many slopes indicate that significant horizontal displacement, probably caused by frost action, occurs at early stages in the rockfall process. The collision of a large block with a relatively thick vegetated soil mat downslope may trigger a debris avalanche.

or bench, they may tumble and develop rotational momentum. An excellent example of block slides, which exhibited both translational and rotational movement, is at White Rocks Recreation Area, $29 \mathrm{~km}$ south of Rutland (site 4, fig. 13; fig. 16). The rock here is moderately massive Cambrian Cheshire Quartzite. The westerly facing mountainside at this location is parallel to the dip of the bedding. Initial block sliding was probably in response to freeze-thaw cycling. Under such conditions, large blocks that have become unstable more than likely slid down the dip slope of a joint, destroying trees (fig. 17).

\section{Topples}

Topples are not a common type of rock-slope failure in Vermont, mainly because the geologic and topographic conditions that promote their formation are not common. In this failure mode, major movement occurs where foliation and (or) bedding have high dip angles and low base slope angles. Closely spaced bedding or foliation favors topples, as opposed to larger, more massive rock, which is prone to rockfalls.

Possibly, a topple failure is developing on Mad Tom Brook near East Dorset (site 7, fig. 13). The rock, 


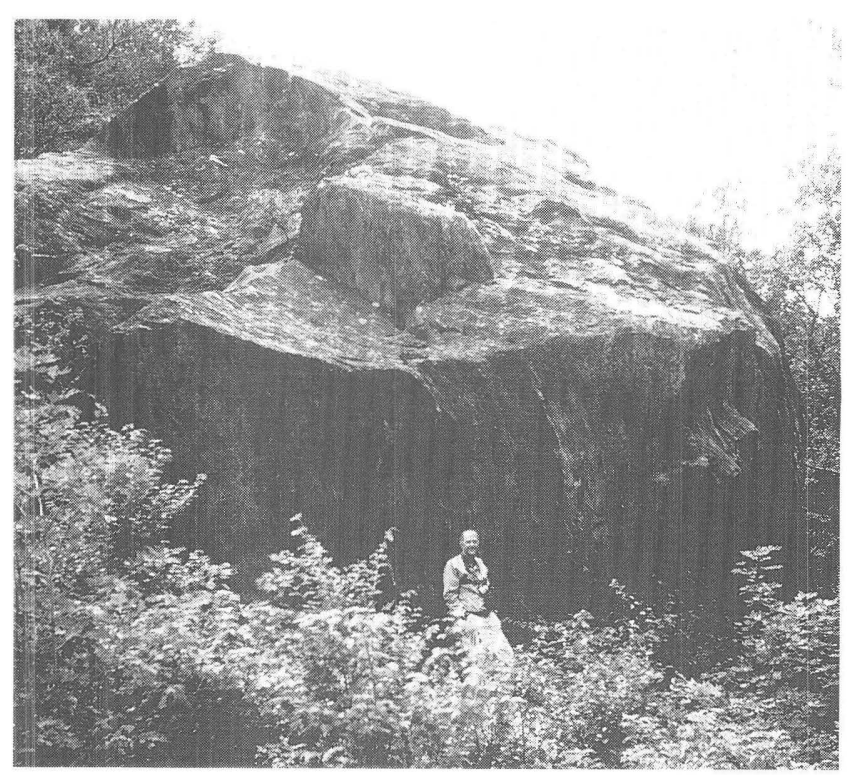

Figure 15. The 6,000-ton King Rock on Vermont Route 108 in Smugglers Notch. Note the person in front of the rock for scale.

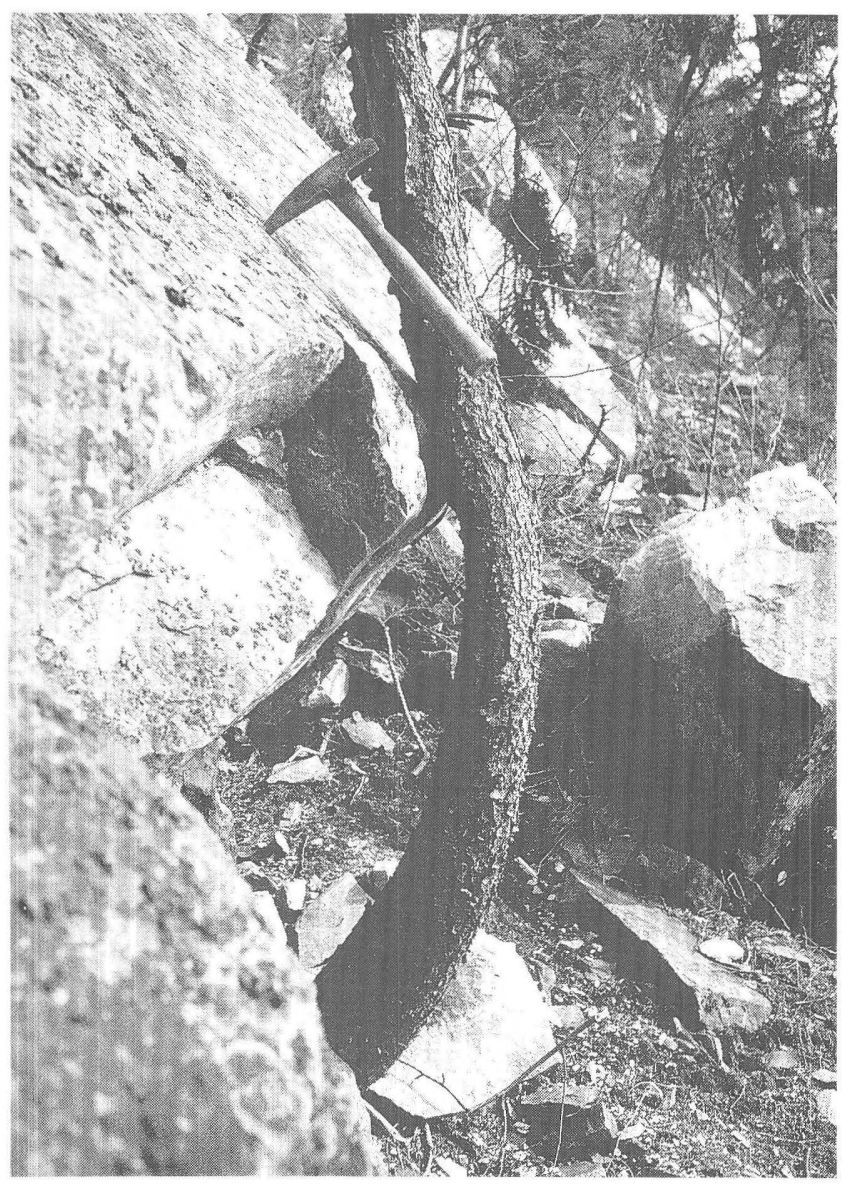

Figure 16. Block slide at White Rocks, near Wallingford, south of Rutland (site 4, fig. 13). Bedding dips down to the right (west).

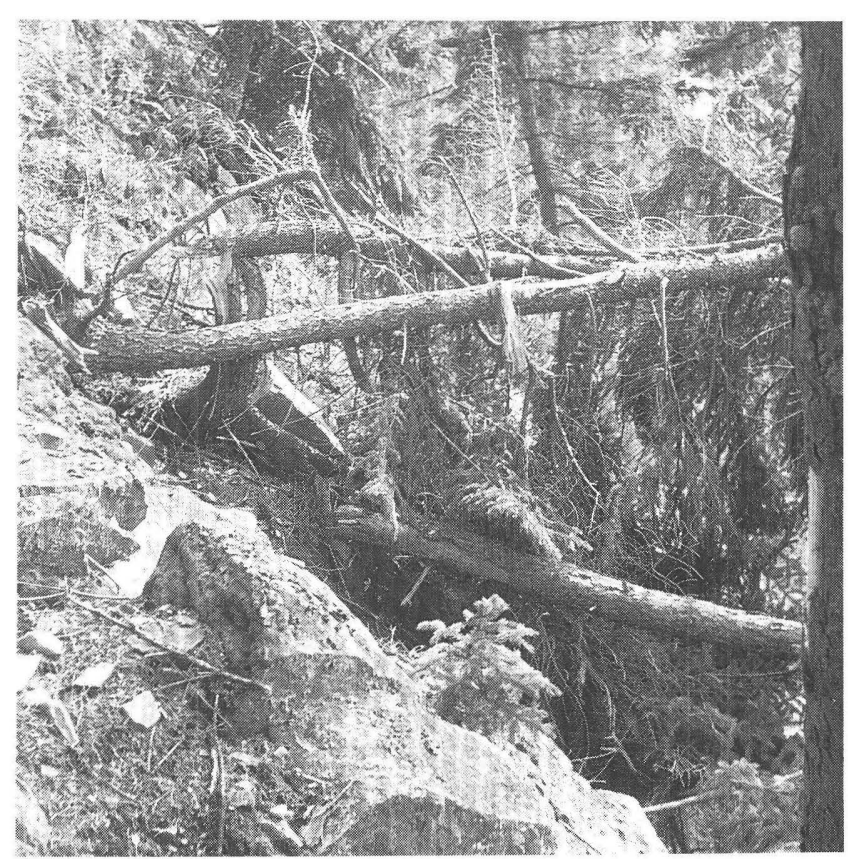

Figure 17. Damage to trees caused by blocks of Cheshire Quartzite tumbling down the dip slope. The block movements occurred in the early spring, the characteristic time for freeze-thaw-induced displacements.

moderately to severely fractured Cheshire Quartzite, contains thin beds of graphitic schist. Figure 18 illustrates how slope deformation may enhance topples. Slope movements have rotated the beds so their strike is about parallel to the brook. The slide axis, oriented N. $50^{\circ} \mathrm{W}$, has an average slope of $60^{\circ}$. At the headwall and near the base, the beds are vertical to overturned. The slope distance is $37 \mathrm{~m}$. Although streamflow is rapid and water levels change dramatically in response to precipitation, our observations show that little undercutting of the toe is now occurring. Displacements are primarily at the headwall scarp and midway down the slide axis, where a prominent bulge has developed. While sliding-friction angles of blocks are as high as $55^{\circ}$ on slopes underlain by massive, unaltered quartzite (as at the White Rocks Recreation Area mentioned in the previous section), the sliding-friction angles determined at the Mad Tom site are in the range of $30^{\circ}$ to $40^{\circ}$ (Lee, 1989). The overall slope angle is greater than this range because at many locations on this slope (1) no well-developed, throughgoing weakness surfaces are parallel to the strike of the bedding, (2) individual blocks are commonly keyed or interlocked with adjacent blocks, and (3) beds are dipping into the slope. These structural conditions make overturning and toppling mechanically more likely than sliding. The overturning and toppling beds shown in figure 18 are moving at an average rate of 44 


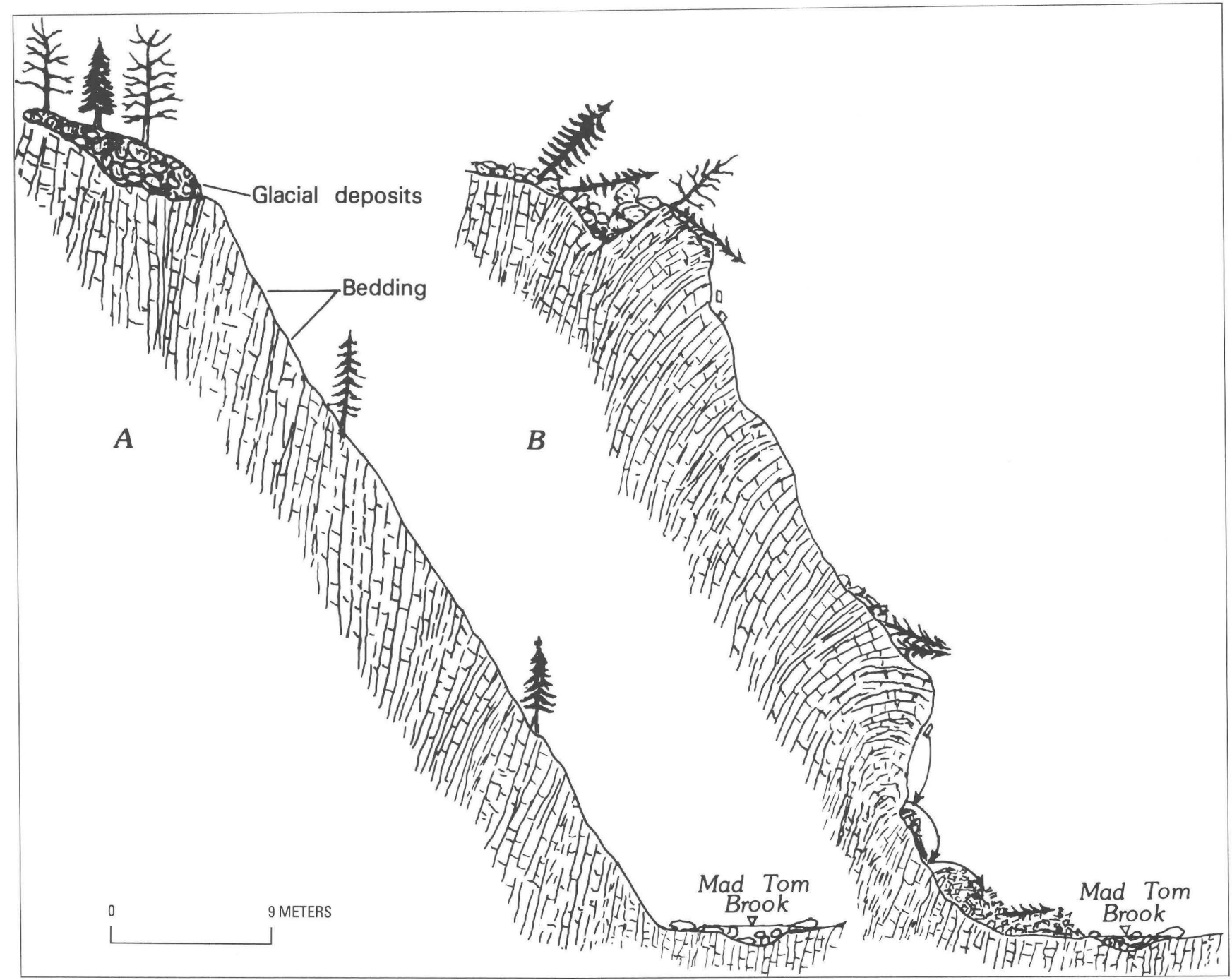

Figure 18. Slope deformation in Cheshire Quartzite at Mad Tom Brook (site 7, fig. 13), looking west. A, Initial postglacial condition showing steeply dipping beds of quartzite and graphitic schist. Although fracturing is severe, infiltration of water is impeded by schistose layers and the steepness of the slope. The stream is not actively downcutting its bedrock channel. $B$, Present condition of the

$\mathrm{mm} / \mathrm{yr}$ (F.T. Lee, unpub. data, 1989); these data are based on 3 years worth of slope instrumentation. Overturning produces unstable overhangs; individual blocks tumble downslope, and many reach the brook below.

Much of the smaller debris falling from the slope washes away in the spring floods of Mad Tom Brook. The streambed contains large, well-rounded glacial boulders and large pieces of slide debris that the stream has been unable to transport. A sudden failure of a large part of the slope could likely dam the entire stream width. A partial damming occurred when a section on the east end of the slope failed in the early 1980 's. slope. A topple has formed because of overturning of beds, particularly at the top and near the base of the slope. Bending has opened joints at several locations, and most deformation is by discrete displacement of blocks rather than by changes in block geometry. Access of rainfall and snowmelt to the rock mass has now been greatly increased.

\section{SLOPE MOVEMENTS ON VERMONT'S INTERSTATE HIGHWAYS}

\section{History and Construction of the System}

Construction of Vermont's Interstate Highway System began in 1956 and took 26 years to complete (fig. 19). In southeastern Vermont, work on I-91 began in 1956

Figure 19. The location of Interstates 89 and 91 and the periods of their incremental construction. The locations of rockslides and rockfalls and their dates of occurrence are also shown. 


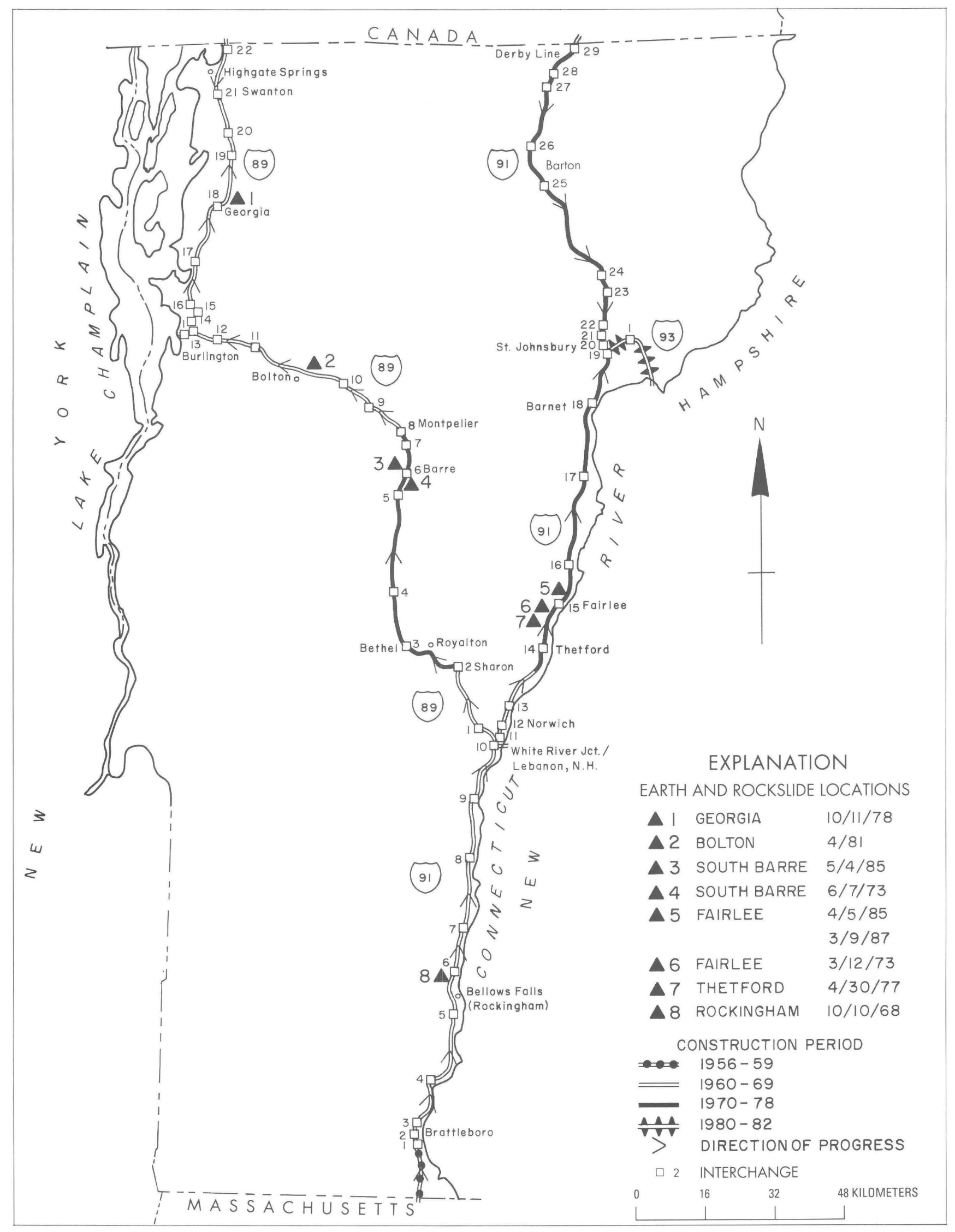


and progressed northward from the Vermont-Massachusetts border. In 1970, construction started at the Canadian border on I-91 in Derby Line and progressed southward. A link with I-91 to I-93 in New Hampshire, east of St. Johnsbury, was completed in 1982. Construction of I-89 started in 1960 in Montpelier and headed north. In 1963 construction began on I-89 from Highgate at the Canadian border and progressed southward. The south end of I-89 went to contract at White River Junction in 1966 and progressed northwestward.

\section{General Geology}

Highway contractors encountered many kinds of rocks during construction (fig. 20). The dominant strike orientation of both bedding and foliation of Vermont bedrock is north or northeasterly. East of the Green Mountain front, the foliation of the folded and metamorphosed bedrock units dips vertically or is near vertical (steep east and (or) west dips). These attitudes are typical along major portions of both I-91 and I-89 (fig. 21). However, north of Interchange 18 on I-91, in the Barnet-St. Johnsbury area, the highway right-of-way is almost exclusively within two bedrock formations, the Silurian(?) Waits River Formation and Lower Devonian Gile Mountain Formation (Doll and others, 1961). These rock units consist mainly of schist, phyllite, and crystalline limestone (fig. 20 ). The bedding and (or) foliation of these formations at this location dip more gently $\left(20^{\circ}\right.$ to $\left.30^{\circ}\right)$ to the east and west. Mostly, the strikes of bedding, foliation, and formational contacts are parallel.

West of the Green Mountain front, at Interchange 13 in South Burlington and north to the Canadian border, the I-89 right-of-way is in folded and faulted sedimentary bedrock of Cambrian and Ordovician age (fig. 20). Limestones, dolomites, and shales define the sedimentary units in northwestern Vermont, and their sedimentary characteristics are maintained. However, a secondary metamorphic cleavage foliation also is present in these rocks. The highway crosses the contacts of north-striking formations at an acute angle in this area. These rock units vary in dip from very gentle $\left(3^{\circ}\right.$ to $\left.5^{\circ}\right)$ to vertical. Bedding, the dominant planar feature in these formations, dips both easterly and westerly.

\section{Design, Design Changes, and Construction of Rockcuts}

Design of the Interstate Highway System, including rockcut slope design, was done by both State and consulting engineers. Consulting firms designed $177 \mathrm{~km}$, and State engineers designed $346 \mathrm{~km}$ of the system.

Before 1972, specifications for rock excavation blasting did not include presplitting, which helps maintain the integrity and stability of the finished rock face by reducing undercutting of the slope toes. As early as 1966, some contractors, for convenience, practiced presplitting blasting procedures to better control the volume of rock eligible for payment. Early design, therefore, was based on economy of construction, cost of right-of-way that the State would have to buy, and whether right-of-way was available. By 1972, I-89 was finished, and I-91 was completed between the Massachusetts line and Fairlee on the south, and between the Canadian border and Barton in the north (fig. 19).

Rockcut slope design called for 4 (vertical) on 1 (horizontal) slopes throughout the system. Rock type and structure were ignored in slope design. Precedence for the value of such consideration was evident in mountainous terrains in other States. Similar construction had occurred or was in progress in Pennsylvania at the same time Vermont's interstate system was under construction (Philbrick, 1953; Flint and Hamel, 1971).

In 1972, Section 207 of the Standard Specifications for Highway and Bridge Construction (Vermont Department of Highways, 1972) and later revisions contained procedures for rock blasting including presplitting. Additionally, under Section 203.04 of the manual, in describing rock excavation, wording included details on controlled blasting procedures for rockcut slopes. However, presplitting techniques did not include specifications for cutting slopes parallel to dips on existing foliation or other planar surfaces in metamorphic rock. As a result, toes of slopes were often undercut. Many segments of the interstate have rockcut slope faces constructed at steeper angles than the dip angle of the foliation or bedding planes. Thus, potentially unstable and hazardous conditions were created in places where undercut and unsupported slabs sloped toward the highway. These conditions are similar to the "overdip" situations described by Pomeroy (1982) in Pennsylvania where the natural slope is steeper than the dip angle.

In 1971, design specifications for newly constructed slopes extended the rockfall area at the base of slopes (called the clear zone) from $7 \mathrm{~m}$ to $9 \mathrm{~m}$. The use of the $9-\mathrm{m}$ width for clear zones was the result of tests that showed this width is a safer "recovery" distance for drivers who have lost vehicular control and strayed from the paved highway. A secondary benefit was the creation of a wider fall zone that could prevent some rockfalls from entering the traveled portion of the highway. In 1972, a change was made in the clear zone by adding a mound of rounded earth at the toe of each rockcut slope. This was also a safety measure to redirect errant drivers away from the rock slope face and secondarily to cushion falling rock.

Figure 20. Generalized geologic map of Vermont (modified from Doll and others, 1961). 


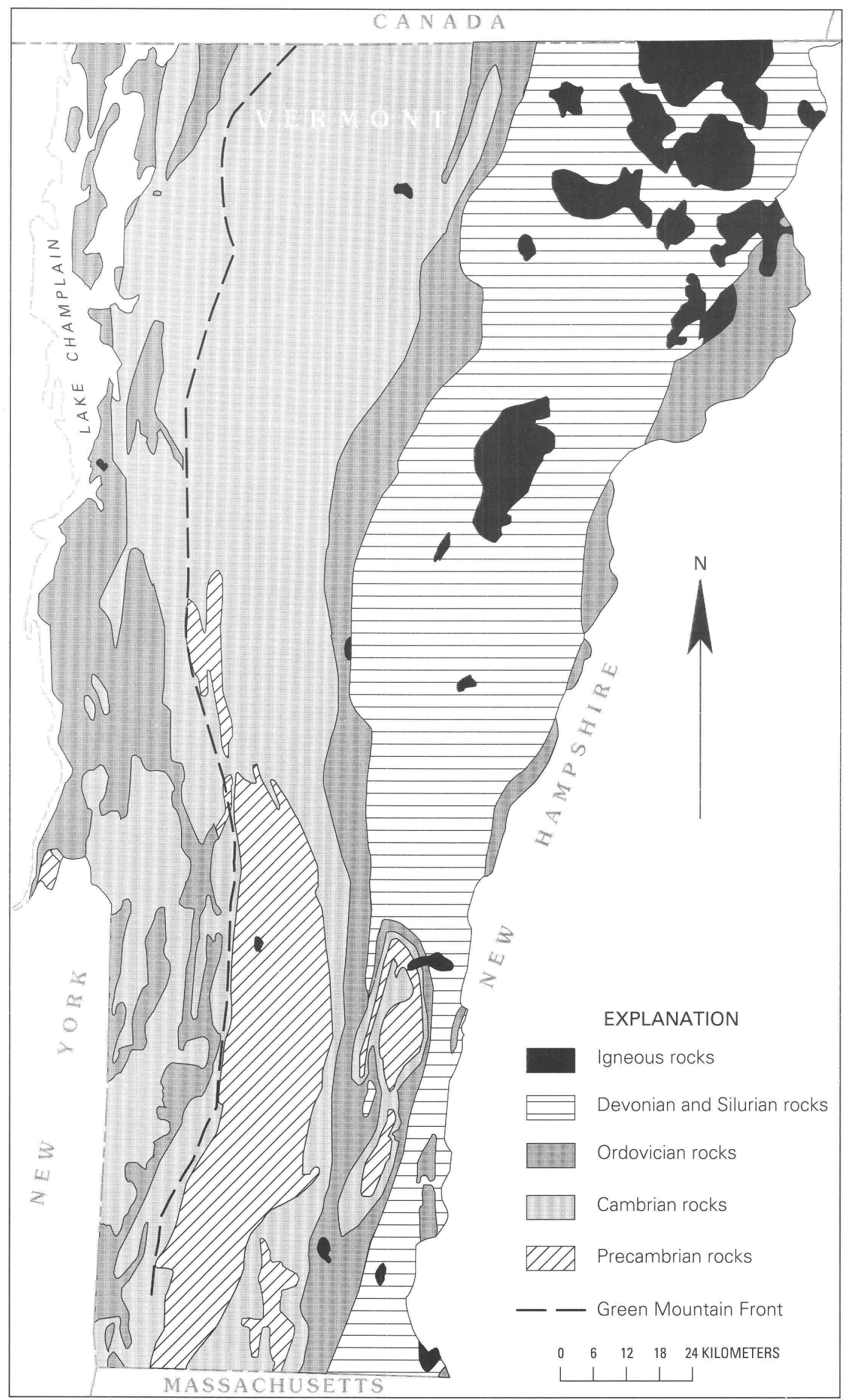




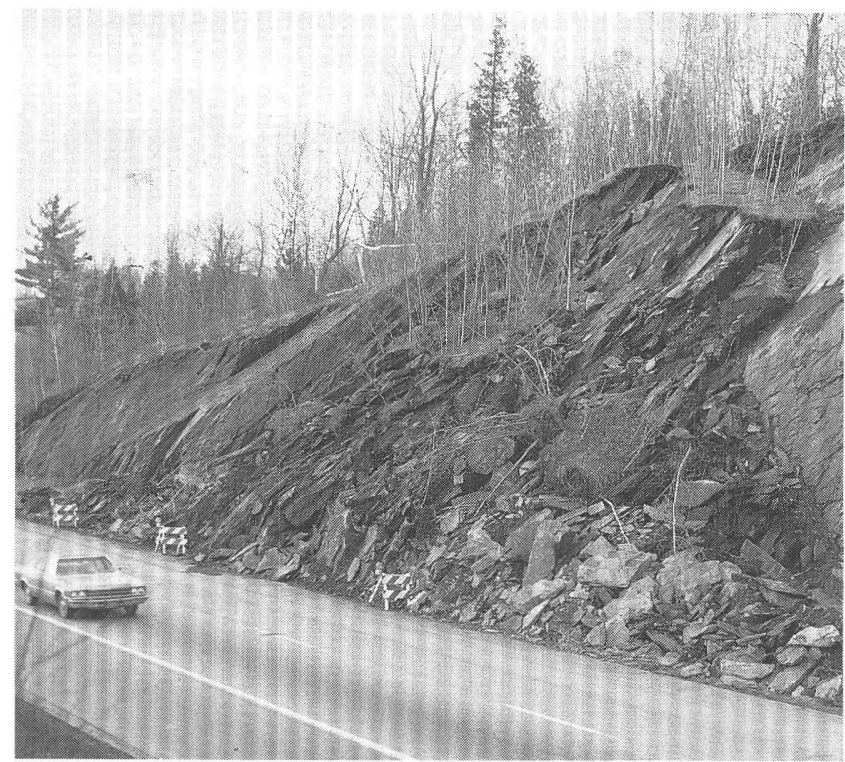

Figure 21. Rockslide of May 4, 1985, along the southbound roadway of Interstate 89 at South Barre (location 3, fig. 19). Foliation dips approximately $60^{\circ}$ east (toward the highway). Such dip surfaces serve as failure surfaces.

In some areas, rock structure conditions presented problems. The use of geological examination and analysis became important in trying to change the standard design. Often, recommendations by highway geologists during construction helped solve problems not considered during the design stage.

\section{Analysis of Rockcuts}

A reconnaissance survey began in the fall of 1977 and spring of 1978 to rate the rockslide-rockfall potential of all rockcuts along the Vermont Interstate Highway System. The State Geologist and the Chief Geologist of the Agency of Transportation collaborated in this survey. This reconnaissance was the first of an intended three-phase program (Ratté, 1978). In Phase I, these geologists made an assessment of all bedrock cuts over $6 \mathrm{~m}$ in height. These cuts were checked and given a hazard rating based on 7 criteria (table 2). A rating of 1 showed a low hazard; a rating of 10 was an extreme hazard. Phase II called for detailed geological and engineering analysis of those cuts thought to present the most hazard to public health and safety. Phase III would provide recommendations for and implementation of remedial work, and a plan for continued monitoring. It was expected that new design criteria for rockcuts, which considered geologic conditions unique to Vermont, would evolve from this program.
Table 2. Criteria used in the 1977-78 analysis of rocksliderockfall potential along Vermont's Interstate Highway System

[An evaluation number was selected from each of the seven categories, and these numbers totaled for a final score]

\begin{tabular}{|c|c|}
\hline Criteria & $\begin{array}{l}\text { Evaluation } \\
\text { Number }\end{array}$ \\
\hline \multicolumn{2}{|l|}{ 1. Height of rockcut } \\
\hline$<6 \mathrm{~m} \ldots \ldots \ldots$ & 0 \\
\hline $6 \mathrm{~m}$ to $9 \mathrm{~m} \ldots$ & 1 \\
\hline $9 \mathrm{~m}$ to $12 \mathrm{~m} \ldots \ldots \ldots \ldots \ldots \ldots \ldots \ldots$ & 2 \\
\hline$>40 \mathrm{~m} \ldots \ldots \ldots \ldots \ldots \ldots \ldots \ldots \ldots \ldots \ldots \ldots$ & 3 \\
\hline 2. Distance from toe to pavement if $<6 \mathrm{~m} \ldots \ldots \ldots$ & 1 \\
\hline \multicolumn{2}{|l|}{$\begin{array}{l}\text { 3. Planar geologic structures dipping toward the } \\
\text { highway }\end{array}$} \\
\hline$<30^{\circ} \ldots \ldots \ldots$ & 1 \\
\hline $30^{\circ}$ to $70^{\circ} \ldots \ldots$ & 3 \\
\hline $70^{\circ}$ to $90^{\circ} \ldots \ldots \ldots \ldots \ldots \ldots \ldots \ldots \ldots \ldots \ldots$ & 1 \\
\hline 4. Topographic slope toward highway $\ldots \ldots \ldots \ldots \ldots$ & 1 \\
\hline 5. Presence of ground water and (or) surface water... & 1 \\
\hline 6. Past history of rockslide-rockfall activity $\ldots \ldots \ldots \ldots$ & 1 \\
\hline $\begin{array}{l}\text { 7. Other recognizably adverse conditions (such as } \\
\text { being strongly jointed) } \ldots \ldots \ldots \ldots \ldots \ldots \ldots \ldots \ldots \text {. }\end{array}$ & 1 \\
\hline
\end{tabular}

\section{Rockcut Slope Failures}

Not all problems were solved or recognized. Several large rockslides and rockfalls occurred along Vermont's Interstate Highway System. The large failures that entered or crossed traffic lanes, fortunately, occurred at times of sparse traffic. This latter factor has averted injury to the traveling public. Sites of recorded rockslides and rockfalls are shown with dates of occurrence on figure 19.

Some of the rockcut slope failures are instructive. In the early morning hours of April 5, 1985, a large block of rock fell from near the crest of the Palisades cliff between posted mile 99.75 and 99.85 in Fairlee on southbound I-91 (location 5, fig. 19; fig. 22). The block landed in the fall area and shattered, spraying $11-$ to $21-\mathrm{cm}$-diameter chunks across the southbound lanes. A pickup truck passing the area sustained damage to all four tires. On March 9, 1987, at this same location, a rockfall caused extensive damage to two automobiles (fig. 23); fortunately, the occupants of these vehicles escaped injury.

The bedrock at the Fairlee site is the massive Middle Ordovician(?) Post Pond Volcanic Member of the Orfordville Formation (Doll and others, 1961). It contains multiple intersecting joint sets related to the Ammonoosuc fault, which traverses this area. This rockcut scored 7 in the Phase I study.

Another rockfall of about $3,500 \mathrm{~m}^{3}$ occurred about 7:00 p.m. on October 10, 1968, along southbound I-91 between posted mile 34.70 and 34.90 in Rockingham (location 8, fig. 19). This failure took place along the steep east-dipping foliation in the phyllite-slate unit of the Littleton Formation (Doll and others, 1961) in a very deep, 


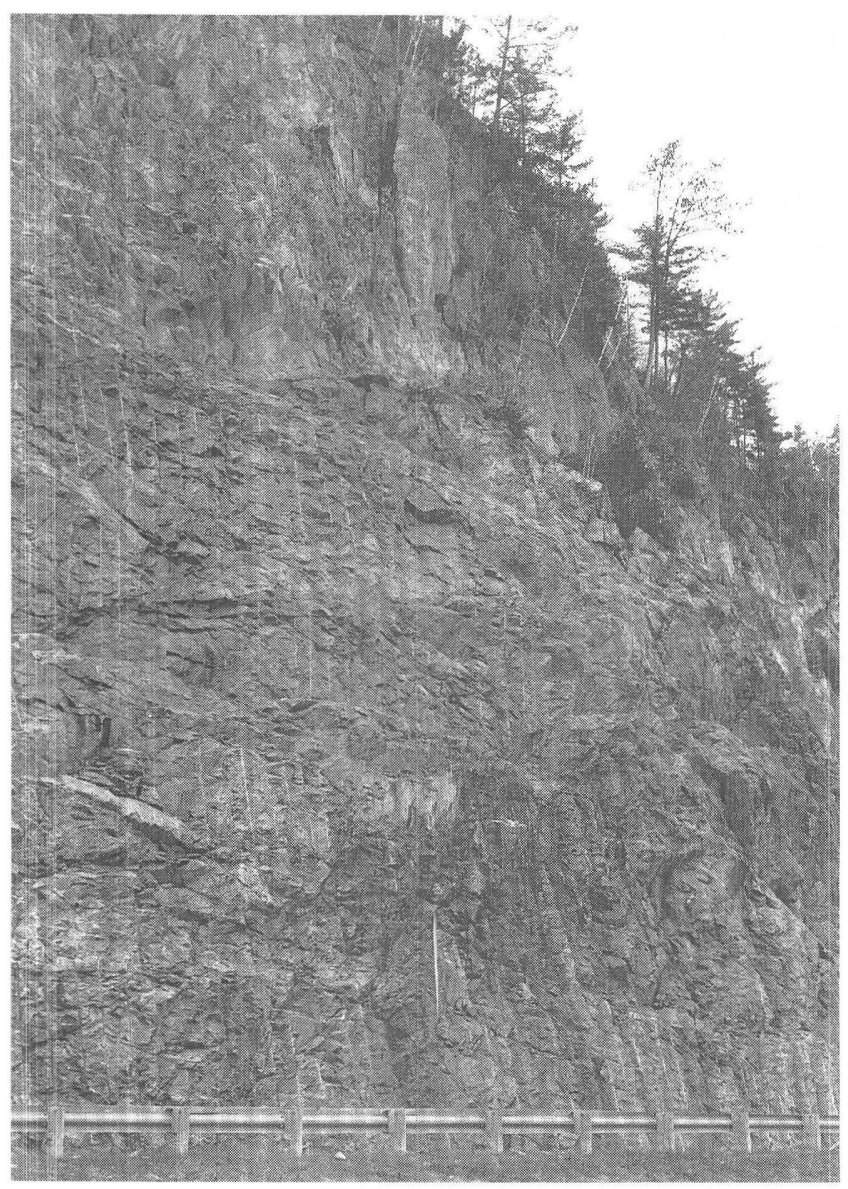

Figure 22. View of the Palisades rockcut at Fairlee (location 5 , fig. 19). The southbound lane is hidden behind the guardrail in the foreground. Loose blocks originated near the crest of this rockcut at a height of several meters above the pre-split area (indicated by the closely spaced drill marks seen on the rock face).

unbenched cut (fig. 24). The slide scar was about $12 \mathrm{~m}$ high and $46 \mathrm{~m}$ wide. Rock debris covered the two southbound lanes.

This type of failure can occur where foliation strikes parallel to the highway and dips steeply toward the highway. Fall areas (clear zones) through these deep cuts are narrow as a result of economic considerations made during original design and construction. This cut scored 9 in the Phase I study.

The Georgia rockfall occurred on the night of October 11,1978 , on the northbound side of I-89 at posted mile 107 between 107.50 and 107.75 (location 1, fig. 19). A massive block of dolomite, weighing several hundred tons, dropped $6 \mathrm{~m}$ to the clear zone next to the traveled lanes of I-89. Several smaller blocks and fragments slid onto the edge of the pavement. This type of rockfall can occur in massive, thick-bedded rock units having penetrating, intersecting joint sets, particularly where bedding planes dip toward the highway. The failure occurred in the Dunham Dolomite of

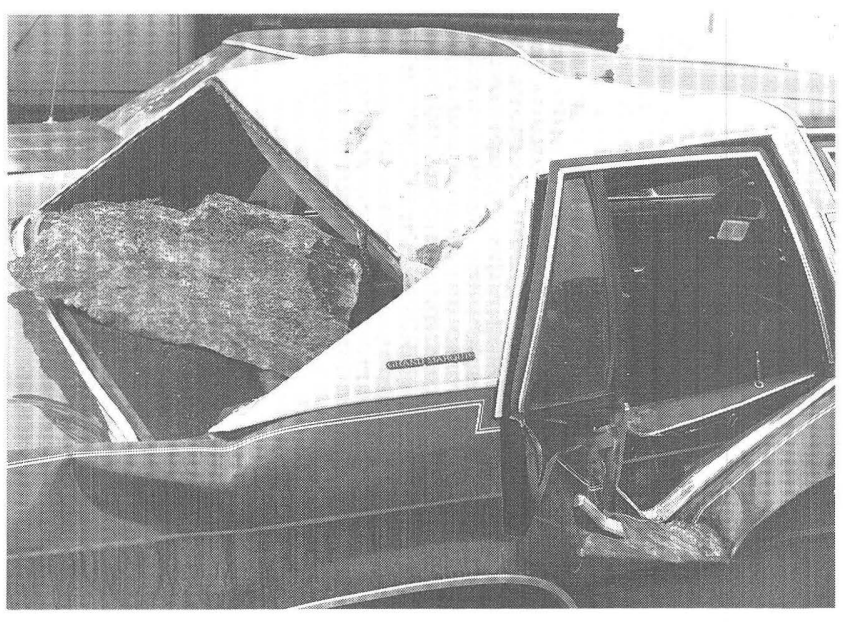

Figure 23. A vehicle damaged by the March 9, 1987, rockfall at Fairlee (location 5, fig. 19).

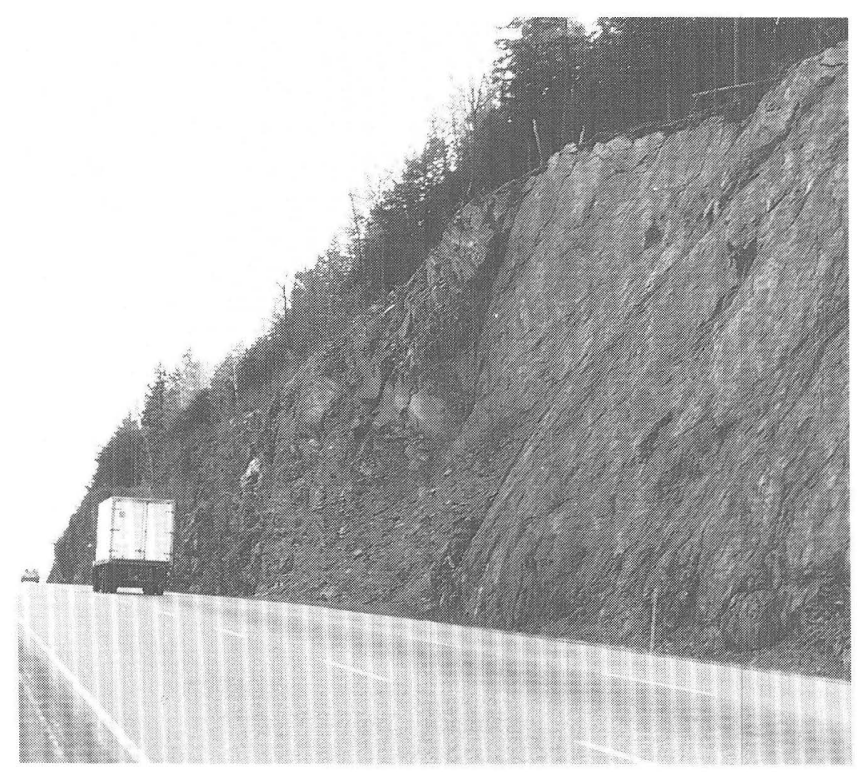

Figure 24. Scar of the October 10, 1968, rockslide near Interchange 6 (Rockingham) on Interstate 91 (location 8, fig. 19). The view is looking south along a steep, eastdipping foliation surface upon which sliding took place. Note the hanging undercut slab at the south end of the cut.

Cambrian age (Doll and others, 1961). Many more bedded and jointed Cambrian sequences dominate the bedrock along I-89 from Burlington to the Canadian border. This site scored a 10 in the Phase I survey.

The last example of rockfalls from Interstate Highway rockcuts is a topple that occurred on southbound I-91 between Thetford and Fairlee on the morning of April 30, 1977 (location 7, fig. 19; fig. 25). The rock is the Meetinghouse Slate Member of the Lower Devonian Gile Mountain Formation (Doll and others, 1961). The foliation 


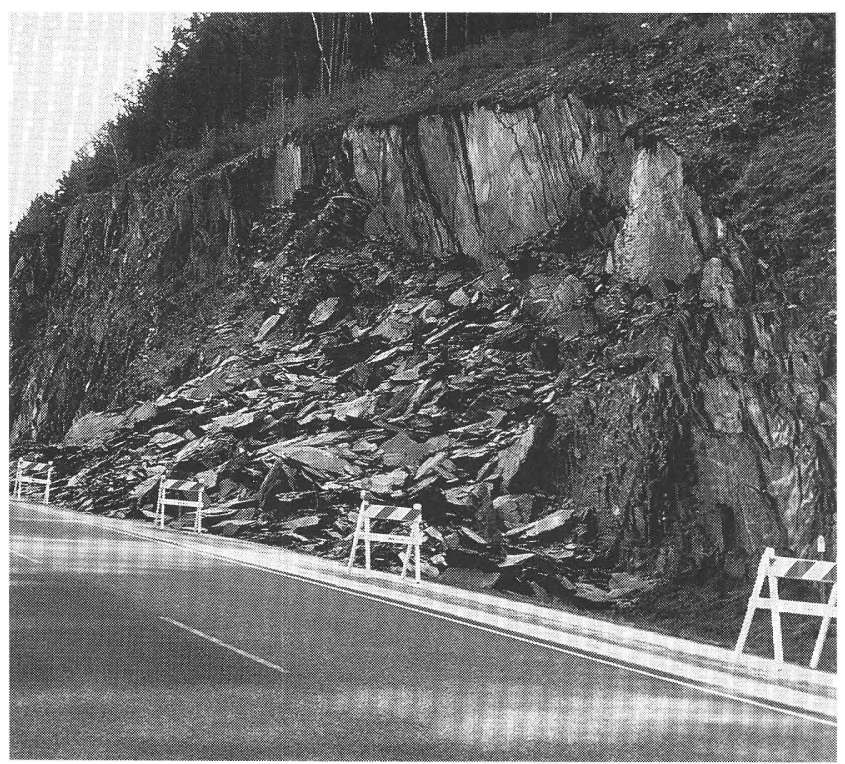

Figure 25. Scar and resulting debris of the April 30, 1977, rockslide along the southbound cut face of Interstate 91 at Fairlee (location 5, fig. 19).

at this site strikes parallel to the highway (northerly) and dips $70^{\circ}$ to $80^{\circ}$ westerly, away from the highway.

\section{Results of the Phase I Project}

The phase I reconnaissance survey rated the interstate highway cuts on the basis of the criteria shown in table 2 . Forty sites received a score of 7 or greater and were given recommendations for detailed geologic and engineering analysis (Phase II). A highway safety reconstruction project began in 1989-90. The intent of this project is to widen all rockcuts that predate 1971 to a 9-m clear zone width between rockcut faces and the road pavement.

\section{CONCLUSIONS}

The cases of landslide events discussed in this paper are presented to create a public awareness of natural hazards and hazards accentuated by humans. When valuable property is exposed to potential landsliding, methods for mitigation need to be weighed. Some of the mitigation procedures may be as simple as the development of a drainage system to lower the water level of the slope. The use of counterweight berms can be applied to prevent further movement on the toes of slopes. When planning the creation of rock slopes, engineers should consider cutting the rock back until as flat a slope as possible is made for stabilization purposes.

Sloping land that has been set aside for tree harvest may be susceptible to landsliding and consequently should be examined carefully for slope stability before clearcutting takes place. Controlled selective cutting and immediate reforestation may be desirable to prevent destruction of these valuable properties.

The design of new highways must be made with a clear understanding of the effects of geologic structure, soil conditions, and drainage on the behavior of constructed slopes. Proper design and construction practice will help assure stable cut slopes and avoid costly maintenance work.

Before commencing commercial or residential development, qualified professionals, such as engineering geologists or geotechnical engineers, should perform a detailed study on land that appears susceptible to landsliding. The State Geologist or individual city or county geologists can be consulted on such subjects. If the situation seems potentially threatening, development should be reconsidered.

\section{REFERENCES CITED}

Baldwin, Theron, 1829, Miscellaneous notices of mountain scenery, and of slides and avalanches in the White and Green Mountains: American Journal of Science, Benjamin Silliman, ed., v. 15, p. 228-232.

Baskerville, C.A., 1990, Landslides induced by floods and torrential rains in Vermont, 1989 [abs.]: Geological Society of America Abstracts with Programs, v. 22, no. 2, p. 3.

Baskerville, C.A., and Ohlmacher, G.C., 1988, Some slopemovement problems in Windsor County, Vermont, 1984: U.S. Geological Survey Bulletin 1828, 25 p.

Baskerville, C.A., Ratté, C.A., and Lee, F.T., 1988, A rockfall and debris slide at Smugglers Notch, Mount Mansfield,Cambridge, Vermont: Vermont Agency of Natural Resources, Studies in Vermont Geology, no. 4, 10 p.

Bates, R.L., and Jackson, J.A., 1980, Glossary of geology (2d ed.): Falls Church, Va., American Geological Institute, $751 \mathrm{p}$.

Doll, C.G., Cady, W.M., Thompson, J.B., Jr., and Billings, M.P., 1961, Centennial geologic map of Vermont: Vermont Geological Survey, scale 1:250,000.

Doll, C.G., Stewart, D.P., and MacClintock, Paul, 1970, Surficial geologic map of Vermont: Vermont Highway Department and Vermont Geological Survey, scale 1:250,000.

El Ashmawi, N., and Greenfield, B.J., 1972, A review of vertical cut slopes in flat layered rock 5 years after construction: Association of Engineering Geologists Bulletin, v. 9, no. 4, p. 395-398.

Eschner, A.R., and Patric, J.H., 1982, Debris avalanches in eastern upland forests: Journal of Forestry, v. 80, no. 6, p. 343-347.

Flint, N.K., and Hamel, J.V., 1971, Engineering geology at two sites on Interstate 279 and Interstate 79 northwest of Pittsburgh, Pennsylvania, in Thompson, R.D., ed., Environmental geology in the Pittsburgh area: Geological Society of America Annual Meeting, Washington, D.C., November 1971, Field Trip Guidebook 6, p. 34-36.

Gary, Margaret, McAfee, Robert, Jr., and Wolf, C.L., eds., 
1972, Glossary of geology: Washington, D.C., American Geological Institute, 805 p.

Goodman, R.E., 1976, Methods of geological engineering in discontinuous rocks: St. Paul, Minn., West Publishing Company, $472 \mathrm{p}$.

Greenway, D.R., Anderson, M.G., and Brian-Boys, K.C., 1984, Influence of vegetation on slope stability in Hong Kong: IV International Symposium on Landslides, University of Toronto, Downsview, Ontario, v. 1, p. 399-404.

Hamblin, W.K., 1989, The earth's dynamic systems: A textbook in physical geology (5th ed.): Macmillan, $576 \mathrm{p}$.

Hoek, Evert, and Bray, J.W., 1977, Rock slope engineering: London, The Institution of Mining and Metallurgy, $402 \mathrm{p}$.

Jibson, R.W., 1989, Debris flows in southern Puerto Rico, in Schultz, A.P., and Jibson. R.W., eds., Landslide processes of the eastern United States and Puerto Rico: Geological Society of America Special Paper 236, p. 29-56.

Lee, F.T., 1989, Slope movements in the Cheshire Quartzite, southwestern Vermont, in Schultz, A.P., and Jibson, R.W., eds., Landslide processes of the eastern United States and Puerto Rico: Geological Society of America Special Paper 236, p. 89-102.

Ohlmacher, G.C., and Baskerville, C.A., 1991, Landslides on fluidlike zones in the deposits of glacial Lake Hitchcock, Windsor County, Vermont: Bulletin of the Association of Engineering Geologists, v. 28, no. 1, p. 1-13.

Philbrick, S.S., 1953, Design of deep rock cuts in the Conemaugh Formation [Pennsylvania/Ohio], in Symposium of Geology as Applied to Highway Engineering, 4th annual, Charleston, W. Va., 1953, Proceedings: Morris Harvey College and West Virginia State Road Commission, p. 79-88.

Piteau, D.R., 1970, Geologic factors significant to the stability of slopes cut in rock, in Van Rensburg, P.W.J., ed., Planning of open pit mines, Symposium on the Theoretical Background to the Planning of Open Pit Mines with Special Reference to Slope Stability, Proceedings: Capetown, S.A., Balkema, p. 33-53.

Pomeroy, J.S., 1982, Landslides in the greater Pittsburgh region, Pennsylvania: U.S. Geological Survey Professional Paper $1229,48 \mathrm{p}$.

Ratté, C.A., 1978, Rock slide hazards project for Vermont's Interstate Highway System [abs.]: Green Mountain
Geologist, v. 4, no. 4, Vermont Geological Society, Montpelier, Vt., p. 10.

Ratté, C.A., and Rhodes, Dallas, 1981, The debris avalanche in the Green Mountains of Vermont: Appalachia, v. 43, no. 3, p. 143-145.

Ritter, D.F., 1986, Process geomorphology (2d ed.): Dubuque, Iowa, W.C. Brown Publishers, 579 p.

Schuster, R.L., Smith, W.K., and Lee, F.T., 1975, Importance of geologic structure in stability of rock slopes, in Slope Stability and Landslides, Sixth Ohio Valley Soils Seminar, Cincinnati Geotechnical Group, American Society of Civil Engineers, p. 1-22.

Sharpe, C.F.S., 1989, Mass movement 1938-1988: Bulletin of the Association of Engineering Geologists, v. 26, no. 3, p. 410-414.

Sowers, G.F., 1979. Introductory soil mechanics and foundations: Geotechnical engineering (4th ed.): MacMillan, $621 \mathrm{p}$.

Terzaghi, Karl, 1962, Stability of steep slopes on hard unweathered rock: Geotechnique, v. 12, no. 4, p. 251-270.

Tharp, T.M., 1984, Stability of slopes in discontinuously jointed rock, in Dowding, C.H., ed., Rock mechanics in productivity and protection: 25th Symposium on Rock Mechanics, Evanston, Ill., Proceedings: New York, American Institute of Mining, Metallurgical, and Petroleum Engineers, p. 891-898.

Varnes, D.J., 1958, Landslide types and processes, in Eckel, E.B., ed., Landslides and engineering practice: Highway Research Board, Special Report 29, National Academy of Sciences, Wash., D.C., p. 20-47.

1978, Slope movement types and processes, in Schuster, R.L., and Krizek, R.J., eds., Landslides analysis and control: Transportation Research Board, Special Report 176, National Academy of Sciences, Wash., D.C., p. 11-33.

Vermont Department of Highways, 1971, Design standards for road and bridge construction: State of Vermont, Department of Highways, Montpelier, Vt., Standard A-2, Interstate and Arterial Typical Section, approved December 8, 1971.

1972, Standard specifications for highway and bridge construction: State of Vermont, Department of Highways, Montpelier, Vt., 670 p.

Yamaguchi, Shinichi, chief ed., 1980, Landslides in Japan [no. 3]:[Tokyo] The Japan Society for Landslide and National Conference of Landslide Control, 44 p. 



\section{SELECTED SERIES OF U.S. GEOLOGICAL SURVEY PUBLICATIONS}

\section{Periodicals}

Earthquakes \& Volcanoes (issued bimonthly).

Preliminary Determination of Epicenters (issued monthly).

\section{Technical Books and Reports}

Professional Papers are mainly comprehensive scientific reports of wide and lasting interest and importance to professional scientists and engineers. Included are reports on the results of resource studies and of topographic, hydrologic, and geologic investigations. They also include collections of related papers addressing different aspects of a single scientific topic.

Bulletins contain significant data and interpretations that are of lasting scientific interest but are generally more limited in scope or geographic coverage than Professional Papers. They include the results of resource studies and of geologic and topographic investigations, as well as collections of short papers related to a specific topic.

Water-Supply Papers are comprehensive reports that present significant interpretive results of hydrologic investigations of wide interest to professional geologists, hydrologists, and engineers. The series covers investigations in all phases of hydrology, including hydrogeology, availability of water, quality of water, and use of water.

Circulars present administrative information or important scientific information of wide popular interest in a format designed for distribution at no cost to the public. Information is usually of short-term interest.

Water-Resources Investigations Reports are papers of an interpretive nature made available to the public outside the formal USGS publications series. Copies are reproduced on request unlike formal USGS publications, and they are also available for public inspection at depositories indicated in USGS catalogs.

Open-File Reports include unpublished manuscript reports, maps, and other material that are made available for public consultation at depositories. They are a nonpermanent form of publication that may be cited in other publications as sources of information.

\section{Maps}

Geologic Quadrangle Maps are multicolor geologic maps on topographic bases in 7.5- or 15-minute quadrangle formats (scales mainly $1: 24,000$ or $1: 62,500$ ) showing bedrock, surficial, or engineering geology. Maps generally include brief texts; some maps include structure and columnar sections only.

Geophysical Investigations Maps are on topographic or planimetric bases at various scales; they show results of surveys using geophysical techniques, such as gravity, magnetic, seismic, or radioactivity, which reflect subsurface structures that are of economic or geologic significance. Many maps include correlations with the geology.

Miscellaneous Investigations Series Maps are on planimetric or topographic bases of regular and irregular areas at various scales; they present a wide variety of format and subject matter. The series also includes 7.5-minute quadrangle photogeologic maps on planimetric bases that show geology as interpreted from aerial photographs. Series also includes maps of Mars and the Moon.
Coal Investigations Maps are geologic maps on topographic or planimetric bases at various scales showing bedrock or surficial geology, stratigraphy, and structural relations in certain coal-resource areas.

Oil and Gas Investigations Charts show stratigraphic information for certain oil and gas fields and other areas having petroleum potential.

Miscellaneous Field Studies Maps are multicolor or black-andwhite maps on topographic or planimetric bases for quadrangle or irregular areas at various scales. Pre-1971 maps show bedrock geology in relation to specific mining or mineral-deposit problems; post-1971 maps are primarily black-and-white maps on various subjects such as environmental studies or wilderness mineral investigations.

Hydrologic Investigations Atlases are multicolored or blackand-white maps on topographic or planimetric bases presenting a wide range of geohydrologic data of both regular and irregular areas; principal scale is $1: 24,000$, and regional studies are at 1:250,000 scale or smaller.

\section{Catalogs}

Permanent catalogs, as well as some others, giving comprehensive listings of U.S. Geological Survey publications are available under the conditions indicated below from the U.S. Geological Survey, Map Distribution, Box 25286, Bldg. 810, Federal Center, Denver, CO 80225. (See latest Price and Availability List.)

"Publications of the Geological Survey, 1879-1961" may be purchased by mail and over the counter in paperback book form and as a set of microfiche.

"Publications of the Geological Survey, 1962-1970" may be purchased by mail and over the counter in paperback book form and as a set of microfiche.

"Publications of the U.S. Geological Survey, 1971-1981" may be purchased by mail and over the counter in paperback book form (two volumes, publications listing and index) and as a set of microfiche.

Supplements for 1982, 1983, 1984, 1985, 1986, and for subsequent years since the last permanent catalog may be purchased by mail and over the counter in paperback book form.

State catalogs, "List of U.S. Geological Survey Geologic and Water-Supply Reports and Maps For (State)," may be purchased by mail and over the counter in paperback booklet form only.

"Price and Availability List of U.S. Geological Survey Publications," issued annually, is available free of charge in paperback booklet form only.

Selected copies of a monthly catalog "New Publications of the U.S. Geological Survey" are available free of charge by mail or may be obtained over the counter in paperback booklet form only. Those wishing a free subscription to the monthly catalog "New Publications of the U.S. Geological Survey" should write to the U.S. Geological Survey, 582 National Center, Reston, VA 22092.

Note.-Prices of Government publications listed in older catalogs, announcements, and publications may be incorrect. Therefore, the prices charged may differ from the prices in catalogs, announcements, and publications. 
